\title{
Effect of duration of exposure to diets differing in dietary cation-anion difference on Ca metabolism after a parathyroid hormone challenge in dairy cows
}

\author{
A. Vieira-Neto, ${ }^{1,2}$ I. M. R. Leão, ${ }^{1}$ J. G. Prim, ${ }^{1}$ A. C. M. Silva, ${ }^{1}$ M. Nehme Marinho, ${ }^{1}$ R. Zimpel, ${ }^{1,2}$ S. Etheve, ${ }^{3}$ \\ C. D. Nelson, ${ }^{1}$ and J. E. P. Santos ${ }^{1,2 *}$ \\ ${ }^{1}$ Department of Animal Sciences, University of Florida, Gainesville 32611 \\ ${ }^{2} \mathrm{DH}$ Barron Reproductive and Perinatal Biology Research Program, University of Florida, Gainesville 32611 \\ ${ }^{3}$ DSM Nutritional Products Ltd., Basel, 4002 Switzerland
}

\begin{abstract}
Objectives of the experiment were to determine the length of exposure to an acidogenic diet that would elicit changes in acid-base balance, mineral digestion, and response to parathyroid hormone (PTH)-induced changes in blood $\mathrm{Ca}$ and vitamin $\mathrm{D}_{3}$ in prepartum dairy cows. Nonlactating parous Holstein cows $(\mathrm{n}=20)$ at $242 \mathrm{~d}$ of gestation were blocked by lactation $(1$ or $>1)$ and pretreatment dry matter (DM) intake and, within block, they were randomly assigned to a diet with a dietary cation-anion difference (DCAD) of $+200 \mathrm{mEq} / \mathrm{kg}$ of DM (DCAD + 200) or an acidogenic diet with -150 $\mathrm{mEq} / \mathrm{kg}$ of DM (DCAD -150). Water and DM intake were measured and blood was sampled daily. Urine was sampled every $3 \mathrm{~h}$ for $36 \mathrm{~h}$, and then daily. During PTH challenges on $\mathrm{d} 3,8$, and 13 , cows received i.v. PTH 1-34 fragment at $0.05 \mu \mathrm{g} / \mathrm{kg}$ of body weight every 20 min for $9 \mathrm{~h}$ to mimic the pulsatile release of endogenous PTH. Blood was sampled at $0 \mathrm{~h}$, and hourly thereafter until $10 \mathrm{~h}$, and at $12,18,24,36$, and $48 \mathrm{~h}$ relative to each challenge. Acid-base measures and concentrations of ionized $\mathrm{Ca}$ (iCa) in whole blood, and total $\mathrm{Ca}, \mathrm{Mg}$, $\mathrm{P}$, and vitamin $\mathrm{D}$ metabolites in plasma were evaluated. On d 2 and 7, Ca, $\mathrm{Mg}$, and $\mathrm{P}$ balances were evaluated. Cows fed DCAD -150 had smaller blood $\mathrm{pH}$ (7.431 vs. 7.389) and $\mathrm{HCO}_{3}{ }^{-}$(27.4 vs. $22.8 \mathrm{mM}$ ) compared with DCAD + 200, and metabolic acidosis in DCAD -150 was observed $24 \mathrm{~h}$ after dietary treatments started. Concentrations of iCa begin to increase $24 \mathrm{~h}$ after feeding the acidogenic diet, and it was greater in DCAD -150 compared with DCAD +200 by $3 \mathrm{~d}$ in the experiment (1.23 vs. $1.26 \mathrm{mM}$ ). During the PTH challenges, cows fed DCAD -150 had greater concentration of iCa and area under the curve for iCa than those fed DCAD
\end{abstract}

Received June 20, 2020.

Accepted July 29, 2020.

*Corresponding author: jepsantos@ufl.edu
+200 (48.2 vs. $50.7 \mathrm{mmol} / \mathrm{L} \times$ hour), and there was no interaction between treatment and challenge day. Concentration of 1,25-dihydroxyvitamin $\mathrm{D}_{3}$ in plasma did not differ during the PTH challenge, but change in 1,25-dihydroxyvitamin $\mathrm{D}_{3}$ relative to $\mathrm{h} 0$ of the challenge was smaller in cows fed DCAD -150 than cows fed DCAD +200 (44.1 vs. $32.9 \mathrm{pg} / \mathrm{mL}$ ). Urinary loss of Ca was greater in cows fed DCAD - 150 compared with DCAD +200 (1.8 vs. $10.8 \mathrm{~g} / \mathrm{d}$ ); however, because digestibility of $\mathrm{Ca}$ increased in cows fed DCAD -150 (19.7 vs. 36.6\%), the amount of Ca retained did not differ between treatments. Diet-induced metabolic acidosis was observed by $24 \mathrm{~h}$ after dietary treatment started, resulting in increases in concentration of $\mathrm{iCa}$ in blood observed between 1 and $3 \mathrm{~d}$. Collectively, present results indicate that tissue responsiveness to $\mathrm{PTH}$ and changes in blood concentrations of $\mathrm{iCa}$ and digestibility of $\mathrm{Ca}$ are elicited within $3 \mathrm{~d}$ of exposure to an acidogenic diet. The increased apparent digestibility of $\mathrm{Ca}$ compensated for the increased urinary loss of $\mathrm{Ca}$ resulting in similar Ca retention.

Key words: calcium, dairy cow, dietary cation-anion difference, parathyroid hormone

\section{INTRODUCTION}

The onset of lactation results in marked changes in Ca needs because of the irreversible losses due to synthesis of colostrum and milk, thereby resulting in a large proportion of cows unable to maintain normal blood Ca concentrations (Reinhardt et al., 2011). Reductions in blood Ca occur as early as $9 \mathrm{~h}$ before parturition (Megahed et al., 2018), and the nadir usually observed 24 to $48 \mathrm{~h}$ after parturition (Martinez et al., 2012).

Regulation of blood concentrations of ionized $\mathrm{Ca}$ $(\mathbf{i C a})$ is complex and involves intricate endocrine mechanisms with multiple hormones and feedback loops. Calcium-sensing receptors present in the parathyroid gland serve as a key checkpoint to maintain extracel- 
lular concentrations of $\mathrm{iCa}$ and, consequently, total $\mathrm{Ca}$ (tCa) within a very narrow range. Under normal iCa concentrations, parathyroid hormone (PTH) secretion is inhibited by $\mathrm{G}$ inhibitory-dependent suppression of adenylate cyclase (Conigrave, 2016). Conversely, when concentrations of iCa in blood drop, hence reducing Ca-sensing receptor activity, there is an increase in cyclic AMP in the chief cells that results in synthesis and release of PTH. Under hypocalcemia, degradation of PTH is also decreased, and thus more PTH is available for secretion (Morrissey and Cohn, 1979). Parathyroid hormone directly increases renal Ca reabsorption and stimulates maturation of osteoclasts, favoring bone resorption and release of $\mathrm{Ca}$ from bone ( $\mathrm{Fu}$ et al., 2002; van Abel et al., 2005). Furthermore, PTH upregulates the enzyme 1 $\alpha$-hydroxylase or CYP27B1 in the proximal convoluted tubule cells of the kidney, which enhances synthesis of the calciotropic hormone 1,25-dihydroxyvitamin $\mathrm{D}_{3}$ (Fraser and Kodicek, 1973). Gastrointestinal absorption of $\mathrm{Ca}$, urinary Ca reabsorption, and bone resorption of $\mathrm{Ca}$ are highly regulated and stimulated by 1,25-dihydroxyvitamin $\mathrm{D}_{3}$. Altogether, those mechanisms are precisely coordinated to maintain $\mathrm{Ca}$ homeostasis. However, those mechanisms are challenged by the sudden and major demands of $\mathrm{Ca}$ for lactation in dairy cows, which consequently result in postpartum hypocalcemia.

Diet-induced metabolic acidosis is achieved by decreasing the DCAD by manipulating the contents of strong cations, $\mathrm{K}$ and $\mathrm{Na}$, relative to strong anions, $\mathrm{Cl}$ and S. Ender et al. (1971) observed improved Ca homeostasis at the onset of lactation when feeding acidogenic diets to prepartum cows, which later was demonstrated to improve milk yield (Block, 1984). One of the mechanisms by which acidogenic diets improve $\mathrm{Ca}$ homeostasis is by influencing synthesis and activity of hormones involved in mineral metabolism. In fact, synthesis of 1,25-dihydroxyvitamin $\mathrm{D}_{3}$ was reported to be dependent on acid-base status upon a PTH stimulation (Goff et al., 2014). Late-gestation cows fed acidogenic diets for $14 \mathrm{~d}$ had a greater increase in concentration of tCa and 1,25-dihydroxyvitamin $\mathrm{D}_{3}$ in plasma than those fed an alkalogenic diet (Goff et al., 2014), suggesting that the responsiveness of tissues to PTH is enhanced under metabolic acidosis. In dogs, metabolic acidosis has been reported to increase synthesis of PTH and increase PTH response to induced hypocalcemia (Lopez et al., 2002).

In vitro experiments suggested that feeding acidogenic diets increases the flux rate of $\mathrm{Ca}$ from the mucosal to the serosal side of the ruminal epithelia in sheep (Wilkens et al., 2016). This leads to an increase in gastrointestinal absorption of $\mathrm{Ca}$, which might com- pensate for the increased urinary excretion of Ca when cows are fed acidogenic diets (Rodney et al., 2018). In vivo, altering the DCAD has been shown to have mixed effects on mineral digestibility, with some experiments detecting an increase in gastrointestinal absorption of Ca in dry cows fed acidogenic diets (Lomba et al., 1978; Abu Damir et al., 1994), whereas others observed no effect of DCAD on gastrointestinal absorption of Ca (Oehlschlaeger et al., 2014). Renal tubular acidosis induces hypercalciuria (Yeh et al., 2003; Rodney et al., 2018), and thus an incremental increase in gastrointestinal $\mathrm{Ca}$ absorption is seemingly required to maintain Ca balance. However, the effects of diet-induced metabolic acidosis on $\mathrm{Ca}$ digestibility and mineral balance in prepartum dairy cows remain unclear.

We hypothesized that increases in concentrations of $\mathrm{Ca}$ and 1,25-dihydroxyvitamin $\mathrm{D}_{3}$ in plasma induced by PTH would be greater in cows fed acidogenic diets and observed within $3 \mathrm{~d}$ of starting the dietary treatments. Also, we hypothesized that improvements in $\mathrm{Ca}$ homeostasis in cows fed acidogenic diets is, in part, caused by increased gastrointestinal absorption. Therefore, the objectives of the experiment were to determine the length of exposure to acidogenic diets that would elicit an increased response to PTH-induced changes in blood $\mathrm{Ca}$ and vitamin $\mathrm{D}$ metabolism in prepartum dairy cows, and to determine the effects of diet-induced metabolic acidosis on mineral digestibility and retention in dairy cows.

\section{MATERIALS AND METHODS}

The University of Florida Institutional Animal Care and Use Committee approved all procedures involving cows in this experiment under the protocol number 201810528. The experiment was conducted at the University of Florida Dairy Unit (Gainesville, FL) between February and March of 2019.

\section{Cows, Experimental Design, and Dietary Treatments}

Twenty nonlactating parous Holstein cows with a mean $( \pm \mathrm{SD})$ of $241.6 \pm 6.6 \mathrm{~d}$ of gestation were enrolled in the experiment. Eligible cows were those that were apparently healthy and had been dried off from a previous lactation. Cows enrolled in the experiment had completed a mean of $1.80 \pm 0.95$ lactations (10 cows completed 1 lactation, 5 cows completed 2 lactations, 4 cows completed 3 lactations, and 1 cow completed 4 lactations), and the mean BW at enrollment was $758 \pm$ $61 \mathrm{~kg}$. The experiment followed a randomized complete block design in which cows were blocked by parity as lactation 1 or lactation $>1$ and by DMI during the 5 -d 
adaptation period, with each block including 2 cows. Within each block, cows were randomly assigned to 1 of 2 dietary treatments: an alkalogenic diet formulated to contain $+200 \mathrm{mEq} / \mathrm{kg}$ of $\mathrm{DM}(\mathrm{DCAD}+\mathbf{2 0 0}, 10$ cows) or an acidogenic diet with $-150 \mathrm{mEq} / \mathrm{kg}$ of $\mathrm{DM}$ (DCAD -150, 10 cows). Diets were formulated to have the same forage-to-concentrate ratio and similar nutrient composition, except for the contents of strong ions that were manipulated to alter the DCAD to achieve +200 or $-150 \mathrm{mEq} / \mathrm{kg}$ of DM. The DCAD was calculated assuming the same rate of absorption for the strong ions with the following formula: DCAD = $\left[\left(\mathrm{mEq}\right.\right.$ of $\mathrm{K}^{+}+\mathrm{mEq}$ of $\left.\mathrm{Na}^{+}\right)-\left(\mathrm{mEq}\right.$ of $\mathrm{Cl}^{-}+\mathrm{mEq}$ of $\left.\mathrm{S}^{2-}\right)$ ]. Allocation of experimental units to treatments was conducted by one of the investigators. Investigators were not blinded to the dietary treatments.

\section{Housing, Feeding Management, and Feed Analysis}

Cows were housed in a cross-ventilated barn containing 10 individual tiestalls fitted with air mattresses and bedded with sand that was cleaned 4 times daily. The experiment was conducted in 2 periods. In each experimental period, 10 cows were enrolled and assigned to treatments. Cows were moved to the experimental facility $5 \mathrm{~d}$ before the start of the experiment to acclimate to the new environment and daily handling. During the pretreatment period, cows were fed the same diet containing a DCAD of $+200 \mathrm{mEq} / \mathrm{kg}$. The mean DMI during the $3 \mathrm{~d}$ preceding the start of the experiment was used as blocking criteria. Stalls had individual feed bunks and water meters. Diets were offered as TMR twice daily at 0900 and $1500 \mathrm{~h}$, and orts were weighed before the morning feeding. Amounts of feed offered to individual cows were adjusted daily to ensure at least $10 \%$ orts. Diets were formulated to meet or exceed the nutrient requirements established by NRC (2001) for late-gestation nonlactating parous Holstein cows.

Forages and concentrate mixtures were sampled twice weekly, dried in an air-forced oven at $60^{\circ} \mathrm{C}$ for $48 \mathrm{~h}$ with moisture loss recorded, and stored for later analyses. Samples of the TMR in each dietary treatment were composited for each period and analyzed for the following: $\mathrm{OM}\left(512^{\circ} \mathrm{C}\right.$ for $\left.8 \mathrm{~h}\right)$; $\mathrm{NDF}$ using a heat stable $\alpha$-amylase followed by sequential $\mathrm{ADF}$ analysis according to Van Soest et al. (1991) with the Ankom Fiber Analyzer system (Ankom Technology, Macedon, $\mathrm{NY}$ ); $\mathrm{N}$ using an automated quantitative combustion digestion method (AOAC International, 2000; method 990.03) using a N analyzer (FP-528 Nitrogen Determinator, Leco Corporation, St. Joseph, MI); starch using an enzymatic digestion method and subsequent quantification of glucose (Karkalas, 1985); and fat by acid hydrolysis (AOAC International, 2000; method 954.02). Analyses of minerals were performed in a commercial laboratory (Dairyland Laboratory, Arcadia, WI) using inductively coupled plasma MS, except for $\mathrm{Cl}$, which was extracted in water and measured using a chloride analyzer (Model 926 Chloride Analyzer, Corning Lab Products, Tewksbury, MA). Table 1 depicts the ingredient composition and nutrient content of TMR fed in the experiment.

\section{Blood and Urine Sampling}

Blood was sampled by puncture of the coccygeal vessel into $10-\mathrm{mL}$ lithium-heparinized tubes and 10-mL serum-separator evacuated tubes (Vacutainer system, Becton Dickinson Co., Franklin Lakes, NJ) before the beginning of dietary treatments on $\mathrm{d} 0$, and daily during the 16-d experimental period at $0500 \mathrm{~h}$. Tubes were placed in ice and, within $1 \mathrm{~h}$, centrifuged at 2,000 $\times g$ for $20 \mathrm{~min}$ for plasma and serum separation. Plasma and serum were aliquoted, frozen, and stored at $-20^{\circ} \mathrm{C}$ for further analyses. Jugular venous blood was sampled in lithium heparin tubes before the beginning of dietary treatments on $\mathrm{d} 0$ and on experimental d 1,3,8, and 13, and analyzed within 2 min of collection for $\mathrm{pH}$, concentration of $\mathrm{HCO}_{3}^{-}$, base excess, partial pressure of $\mathrm{CO}_{2}$, total dissolved $\mathrm{CO}_{2}$, partial pressure of $\mathrm{O}_{2}$, oxygen saturation, iCa, Na, K, and glucose using a handheld biochemical analyzer (VetScan i-STAT, Cartridge CG8+, Abaxis, Union City, CA).

Urine was sampled before the beginning of dietary treatments on d 0 , and at 3 -h intervals until $36 \mathrm{~h}$ after the beginning of dietary treatments. Subsequently, urine was sampled daily from d 2 to 16 at $0500 \mathrm{~h}$. Urine was collected by perineal stimulation until a clean and copious stream of urine was obtained. Urinary $\mathrm{pH}$ was measured, and samples were frozen at $-20^{\circ} \mathrm{C}$ for further analysis.

\section{Parathyroid Hormone Challenge}

Cows were challenged with PTH on experimental d 3,8 , and 13 . On the day preceding each challenge, an intravenous 14-gauge and 9-cm long catheter (MilacathExtended Use, Mila International Inc., Florence, KY) was fit into the jugular vein of each cow. An extension tube was attached to the catheter (both held $3.9 \mathrm{~mL}$ ). Briefly, the left or right jugular grooves were shaved and cleansed with 3 alternating rounds of scrub and washes. Each sequence of scrubbing was performed with combinations of povidone-iodine scrub followed by a $70 \%$ isopropyl alcohol scrub. Scrubbing was performed from the center of the jugular groove to the 
Table 1. Ingredient composition and nutrient content of dietary treatments

\begin{tabular}{|c|c|c|}
\hline \multirow[b]{2}{*}{ Item } & \multicolumn{2}{|c|}{$\operatorname{Diet}^{1}$} \\
\hline & $\mathrm{DCAD}+200$ & DCAD -150 \\
\hline \multicolumn{3}{|l|}{ Ingredient, \% DM } \\
\hline Corn silage & 60.8 & 60.8 \\
\hline Bermuda grass hay & 8.7 & 8.7 \\
\hline Whole cottonseed & 6.9 & 6.9 \\
\hline Soybean meal, solvent extract & 2.6 & 4.3 \\
\hline Expeller soybean meal ${ }^{2}$ & 9.6 & - \\
\hline Citrus pulp & 5.6 & 6.9 \\
\hline Acidogenic supplement $^{3}$ & - & 7.5 \\
\hline Mycotoxin binder ${ }^{4}$ & 0.5 & 0.5 \\
\hline Magnesium oxide & 0.3 & - \\
\hline Ruminally protected choline ${ }^{5}$ & 0.5 & 0.5 \\
\hline Sodium bicarbonate & 0.6 & - \\
\hline Mineral-vitamin mixture ${ }^{6}$ & 3.9 & 3.9 \\
\hline \multicolumn{3}{|l|}{ Nutrient content, DM basis $( \pm \mathrm{SD})$} \\
\hline $\mathrm{NE}_{\mathrm{J}}{ }^{7} \mathrm{Mcal} / \mathrm{kg}$ & 1.55 & 1.56 \\
\hline OM, \% & $93.3 \pm 0.7$ & $93.3 \pm 0.7$ \\
\hline $\mathrm{CP}, \%$ & $14.5 \pm 0.6$ & $14.2 \pm 1.1$ \\
\hline MP, \% & 9.9 & 9.7 \\
\hline NDF, $\%$ & $45.6 \pm 2.2$ & $48.6 \pm 0.3$ \\
\hline Forage NDF, $\%$ & $35.2 \pm 4.3$ & $35.2 \pm 4.3$ \\
\hline $\mathrm{NFC}^{8} \%$ & $33.1 \pm 3.0$ & $30.5 \pm 1.4$ \\
\hline Crude fat, $\%$ & $3.8 \pm 0.2$ & $3.7 \pm 0.3$ \\
\hline $\mathrm{Ca}, \%$ & $0.73 \pm 0.07$ & $0.69 \pm 0.06$ \\
\hline $\mathrm{P}, \%$ & $0.36 \pm 0.01$ & $0.38 \pm 0.01$ \\
\hline $\mathrm{Mg}, \%$ & $0.45 \pm 0.03$ & $0.40 \pm 0.01$ \\
\hline $\mathrm{K}, \%$ & $1.38 \pm 0.13$ & $1.25 \pm 0.08$ \\
\hline $\mathrm{Na}, \%$ & $0.20 \pm 0.01$ & $0.14 \pm 0.01$ \\
\hline $\mathrm{Cl}, \%$ & $0.35 \pm 0.09$ & $0.99 \pm 0.04$ \\
\hline S. $\%$ & $0.19 \pm 0.01$ & $0.41 \pm 0.01$ \\
\hline $\mathrm{DCAD},{ }^{9} \mathrm{mEq} / \mathrm{kg}$ of $\mathrm{DM}$ & $236 \pm 8$ & $-153 \pm 15$ \\
\hline
\end{tabular}

${ }^{1}$ Cows were assigned to a diet containing a dietary cation-anion difference of $+200(\mathrm{DCAD}+200)$ or $-150 \mathrm{mEq} / \mathrm{kg}$ of DM (DCAD -150) from 247 to $263 \mathrm{~d}$ of gestation.

${ }^{2}$ SoyPlus (Landus Cooperative, Ames, IA).

${ }^{3}$ Bio-Chlor (fermentation product containing dried condensed extracted glutamic acid fermentation product, dried condensed corn fermentation solubles, processed grain byproducts, and magnesium chloride; Arm and Hammer Animal Nutrition, Princeton, NJ).

${ }^{4}$ Novasil Plus (calcium montmorillonite clay, BASF Corp., Florham Park, NJ).

${ }^{5}$ ReaShure $(28.8 \%$ choline chloride, Balchem Corp., New Hampton, NY).

${ }^{6}$ Contents: $76.0 \%$ wheat middlings; $17.1 \%$ calcium carbonate; $4.3 \%$ magnesium oxide; $0.92 \%$ Avalia4 (Zinpro Corp., Eden Prairie, MN); $0.66 \%$ dry vitamin E 50\%; 0.34\% Rumensin 90 (Elanco Animal Health, Greenfield, IN); $0.32 \%$ Sel-Plex 3000 (Alltech, Nicholasville, KY); $0.22 \%$ vitamin and trace minerals (Suwannee Valley Feeds, Trenton, FL); $0.05 \%$ manganese sulfate; $0.04 \%$ vitamin A; $0.02 \%$ ethylenediamine dihydroiodide $9.2 \%$. Each kilogram contained $13.6 \%$ CP, $7.38 \%$ $\mathrm{Ca}, 0.73 \% \mathrm{P}, 3.02 \% \mathrm{Mg}, 0.84 \% \mathrm{~K}, 0.14 \% \mathrm{Na}, 0.03 \% \mathrm{Cl}, 0.01 \% \mathrm{~S}, 515$ $\mathrm{mg}$ of $\mathrm{Zn}, 180 \mathrm{mg}$ of $\mathrm{Cu}, 461 \mathrm{mg}$ of $\mathrm{Mn}, 10 \mathrm{mg}$ of Se, $18 \mathrm{mg}$ of Co, 12 $\mathrm{mg}$ of I, 248,500 IU of vitamin A, 72,000 IU of vitamin D, 3,570 IU of vitamin $\mathrm{E}$, and $730 \mathrm{mg}$ of monensin.

${ }^{7}$ Calculated using the NRC (2001) according to the chemical composition of the dietary ingredients and adjusted for $11 \mathrm{~kg}$ of DMI.

${ }^{8}$ Calculated as follows: $\mathrm{NFC}=\mathrm{DM}-($ ash $+\mathrm{CP}+$ ether extract + $\mathrm{NDF}$ - NDF insoluble CP).

${ }^{9}$ Calculated as follows: DCAD $=\left[\left(\mathrm{mEq}\right.\right.$ of $\left.\left.\mathrm{K}^{+}\right)+\left(\mathrm{mEq} \mathrm{Na}{ }^{+}\right)\right]-[(\mathrm{mEq}$ of $\left.\mathrm{Cl}^{-}\right)+\left(\mathrm{mEq}\right.$ of $\left.\left.\mathrm{S}^{2-}\right)\right]$. periphery to avoid contamination of the surgical site. Upon completion of disinfecting the surgical site, $5 \mathrm{~mL}$ of a solution containing $2 \%$ lidocaine hydrochloride was administered in the subcutaneous space. The catheter was inserted and sutured to the skin, and patency was maintained by flushing with $15 \mathrm{~mL}$ of sterile heparinized saline containing $10 \mathrm{IU}$ of heparin/mL. Catheters were flushed immediately after placement and after each blood sampling instance during the PTH challenge.

Challenges started $2 \mathrm{~h}$ after the morning feeding at $1100 \mathrm{~h}$, and cows had free access to feed and water throughout the challenge that lasted $9 \mathrm{~h}$. If catheters were displaced for any reason, a new catheter was placed in the contralateral jugular relative to the previous jugular.

A solution of PTH was prepared by dissolving $25 \mathrm{mg}$ of bovine PTH, including only the 1-34 peptide fragment with purity of 98\% (A14896-25, AdooQ Bioscience, Irvine, CA) in $2 \%$ BSA and $0.9 \%$ sodium chloride, for a final solution containing a PTH concentration of $20 \mu \mathrm{g} / \mathrm{mL}$. All procedures were performed aseptically under a laminar flow hood using autoclaved laboratory materials at the day of each challenge and kept in the refrigerator at $8^{\circ} \mathrm{C}$ until the beginning of the challenge. For the challenge, cows intravenously received an administration of PTH at $0.05 \mu \mathrm{g} / \mathrm{kg}$ of BW at $20 \mathrm{~min}$ intervals for $9 \mathrm{~h}$. This dose was chosen to reach similar concentration of PTH in plasma of transitioning dairy cows observed on the day after parturition (Vieira-Neto et al., 2017a). Additionally, to further mimic physiological patterns of PTH metabolism, we followed a strict 20 min administration interval because half-life of PTH ranges between 2 and 5 min (Yamashita et al., 2003) and is secreted in a pulsatile pattern that ranges approximately $20 \mathrm{~min}$ between pulses (Samuels et al., 1993).

Blood was sampled using the jugular catheter immediately before the first administration of PTH, and at $1,2,3,4,4.5,5,6,7,8,9,10,12,18,24,36$, and $48 \mathrm{~h}$ after the beginning of the challenge. At each sampling, $20 \mathrm{~mL}$ of blood was aspirated with a syringe and discarded before collecting the specimen used for subsequent assays. Another $20 \mathrm{~mL}$ of blood was aspirated and immediately transferred to $10 \mathrm{~mL}$ of lithium-heparinized and serum-separator evacuated tubes (Vacutainer system, Becton Dickinson Co.), placed in ice, and centrifuged within $1 \mathrm{~h}$ at $2,000 \times g$ for $20 \mathrm{~min}$ for plasma and serum separation. All blood sampling times that coincided with PTH infusion were collected immediately before PTH administration. Plasma and serum were aliquoted and stored at $-20^{\circ} \mathrm{C}$ for further analyses. Blood samples collected before the beginning 
of the first administration of PTH and at 4.5, 9, 18, and $36 \mathrm{~h}$ after were analyzed for blood gases, iCa, and measures of acid-base balance as previously described.

\section{Blood Minerals, Metabolites, and Hormones}

Concentrations of tCa and total $\mathrm{Mg}(\mathbf{t M g})$ in plasma were analyzed by atomic absorption using a spectrophotometer (AAnalyst 200; Perkin-Elmer Inc., Waltham, MA) equipped with a hollow cathode lamp to detect $\mathrm{Ca}$ and $\mathrm{Mg}$ as previously described (Martinez et al., 2012). The intra- and interassay coefficients of variation $(\mathbf{C V})$ were 2.6 and $6.5 \%$ for $\mathrm{tCa}$, and 3.4 and $8.2 \%$ for $\mathrm{tMg}$, respectively. Concentrations of total $\mathrm{P}(\mathbf{t P})$ in plasma were determined using the molybdenum blue method (Quinlan and DeSesa, 1955). The intra- and interassay CV were 1.7 and $6.3 \%$, respectively.

Concentrations of 1,25-dihydroxyvitamin $\mathrm{D}_{3}$ in plasma were analyzed by ELISA $\left[1 \alpha, 25(\mathrm{OH})_{2}\right.$ Vitamin D ELISA; IBL-America, Minneapolis, MN] according to the manufacturer's instructions (https://www.ibl -america.com/content/elisa/KAR1921.pdf). This assay uses disposable silica cartridges and different solvents to separate the major vitamin D metabolites, which improves the ability of antibodies to detect 1,25-dihydroxyvitamin $\mathrm{D}_{3}$ in plasma. The same assay has been previously used in experiments in which exogenous 1,25-dihydroxyvitamin $\mathrm{D}_{3}$ was administered at different doses to dairy cows and resulted in clear differences in concentrations of 1,25-dihydroxyvitamin $\mathrm{D}_{3}$ in plasma (Vieira-Neto et al., 2017a, 2021). The intra- and interassay CV were 6.8 and $11.4 \%$, respectively. Concentrations of vitamin $\mathrm{D}_{3}, 25$-hydroxyvitamin $\mathrm{D}_{3}, 3$-epi25-hydroxyvitamin $\mathrm{D}_{3}$, and 24,25-dihydroxyvitamin $\mathrm{D}_{3}$ in plasma were analyzed using ultra-HPLC (1290 Infinity II LC System; Agilent, Santa Clara, CA) coupled with tandem MS detection (API 4000 LC-MS/MS System; AB Sciex LLC, Framingham, MA) by the DSM Nutritional Products Research and Development Solution Center (Kaiseraugst, Switzerland). In all assays, dedicated standard and quality-control samples were analyzed with unknown samples to ensure the accuracy and precision of the method. Data acquisition, integration, and quantification were performed by the Analyst software (AB Sciex LLC). Personnel running the assays were blind to treatments, and the lower limits of quantification for the assays were $0.5 \mathrm{ng} / \mathrm{mL}$ for vitamin $\mathrm{D}_{3}$, 3-epi-25-hydroxyvitamin $\mathrm{D}_{3}$, and 24,25-dihydroxyvitamin $\mathrm{D}_{3}$, and $1.0 \mathrm{ng} / \mathrm{mL}$ for 25-hydroxyvitamin $\mathrm{D}_{3}$. The intraassay CV were $4.6,3.6,4.5$, and $6.2 \%$ for vitamin $\mathrm{D}_{3}, 25$-hydroxyvitamin $\mathrm{D}_{3}, 3$-epi-25-hydroxyvitamin $\mathrm{D}_{3}$, and 24,25-dihydroxyvitamin $\mathrm{D}_{3}$, respectively.

The diet fed to cows in both treatments was supplemented with 2,800 IU of vitamin $\mathrm{D}_{3}$ per kilogram of
DM. Concentrations of vitamin $\mathrm{D}_{3}$ and the more stable metabolite 25-hydroxyvitamin $\mathrm{D}_{3}$ and its epimeric form, 3-epi-25-hydroxyvitamin $\mathrm{D}_{3}$, were quantified to determine vitamin D status of cows. Concentrations of 24,25-dihydroxyvitamin $\mathrm{D}_{3}$ were quantified to understand if treatments would affect catabolism of 25-hydroxyvitamin $\mathrm{D}_{3}$ and 1,25-dihydroxyvitamin $\mathrm{D}_{3}$ mediated by CYP24A1. Finally, 1,25-dihydroxyvitamin $\mathrm{D}_{3}$, the active form of vitamin $\mathrm{D}$, was quantified to understand if dietary treatments would influence conversion of 25-hydroxyvitamin $\mathrm{D}_{3}$ to 1,25 -dihydroxyvitamin $\mathrm{D}_{3}$, a reaction catalyzed by CYP27B1, which is stimulated by PTH and previously shown to be affected by acidogenic diets (Goff et al., 2014).

Basal concentrations of PTH on $\mathrm{d} 3$ of the experiment were analyzed by ELISA (Bovine IPTH ELISA kit; Creative Diagnostics, New York, NY) in a single assay according to the manufacturer's instructions (http:// img2.creative-diagnostics.com/pdf/DEIA1826B.pdf). The intraassay CV was $14.4 \%$.

\section{Mineral Balance}

Fecal samples were collected 4 times daily at 6 -h intervals on experimental d 2 and 7 . Orts from each individual cow referent to experimental d 1, 2, 6, and 7 were collected. Forages and grain mixes were collected throughout the sampling period. Samples were dried in an air-forced oven at $60^{\circ} \mathrm{C}$ for $48 \mathrm{~h}$. Samples were ground to pass a 1-mm screen of a Wiley mill (Thomas Scientific, Swedesboro, NJ), and analyzed for DM at $105^{\circ} \mathrm{C}$ for $24 \mathrm{~h}$. Dried orts referent to d 1 and 2 for an individual cow were composited and identified as experimental d 2, whereas orts referent to d 6 and 7 were composited and identified as experimental $\mathrm{d} 7$. Individual ingredients samples referent to each period were composited before analysis.

Individual ingredients, orts, and fecal samples were analyzed for $\mathrm{Ca}, \mathrm{Mg}$, and $\mathrm{P}$ by acid digestion. Briefly, 2 $\mathrm{g}$ of samples were weighted and heated $\left(600^{\circ} \mathrm{C}\right.$ for $\left.8 \mathrm{~h}\right)$ in crucibles, and ash content was determined. Next, 10 $\mathrm{mL}$ of $3 \mathrm{~N} \mathrm{HCl}$ was added, crucibles were covered with watch glasses, and samples were boiled on a hot plate for $10 \mathrm{~min}$ for acid digestion. Crucibles were rinsed with deionized water, and samples were filtered and placed into a $100-\mathrm{mL}$ volumetric flask that was then filled with deionized water. After, samples were diluted to 1:20 and 1:400 using 1\% lanthanum solution (117.3 g of lanthanum oxide diluted into $500 \mathrm{~mL}$ of $3 \mathrm{~N} \mathrm{HCl}$, and further diluted to reach $10 \mathrm{~L}$ using deionized water) for measurements of $\mathrm{Ca}$ and $\mathrm{Mg}$, respectively, or 1:2 using deionized water for measurements of $\mathrm{P}$. All procedures were performed in duplicate. Concentrations of $\mathrm{Ca}$ and $\mathrm{Mg}$ were analyzed by atomic absorption using a 
spectrophotometer (AAnalyst 200; Perkin-Elmer Inc.) equipped with a hollow cathode lamp to detect Ca and $\mathrm{Mg}$ as previously described (Martinez et al., 2012). The intra- and interassay CV were 4.7 and $2.2 \%$ for Ca, and 7.1 and $7.6 \%$ for $\mathrm{Mg}$, respectively. Concentrations of $\mathrm{P}$ were determined using the molybdenum blue method (Quinlan and DeSesa, 1955). The intra- and interassay CV were 5.2 and $5.9 \%$, respectively.

Indigestible NDF (iNDF) was used as a marker to estimate total fecal output. Feed ingredients, individual cow feces, and orts were prepared in quadruplicates, with 2 samples from each specimen incubated in the rumen of 2 cannulated cows for $288 \mathrm{~h}$ for in situ digestion as previously described (Huhtanen et al., 1994). Following in situ incubation, bags were retrieved and the residue analyzed for NDF as previously described. The mean intraassay CV within cow was $3.1 \%$, whereas between cows was $6.8 \%$.

Urine was sampled 4 times daily at 6 -h intervals on d 2 and 7 . Samples were collected by perineal massage until a clean and copious stream of urine was obtained. Urinary $\mathrm{pH}$ was measured in all samples, which were composited into 1 representative sample for each cow on $\mathrm{d} 2$ and 7 and frozen at $-20^{\circ} \mathrm{C}$ until further analyses. Urine samples were analyzed for concentrations of creatinine in duplicates in a single assay using a commercial colorimetric method (Creatinine Urinary Detection Kit; Arbor Assays, Ann Arbor, MI). The intraassay CV was $2.5 \%$. Concentrations of $\mathrm{Ca}$ and $\mathrm{Mg}$ in urine were assayed after samples were diluted 1:400 with $0.5 \%$ lanthanum chloride, followed by analysis by atomic absorption using a spectrophotometer (AAnalyst 200; Perkin-Elmer Inc.). Urinary $\mathrm{Ca}$ and $\mathrm{Mg}$ assays were performed as a single assay, and the intraassay CV were 5.2 and $1.2 \%$ respectively.

Daily urinary volume was estimated using concentrations of creatinine based on the constant excretion of 29 $\mathrm{mg}$ of creatine per kilogram of BW per day (Valadares et al., 1999). Daily urinary volume was calculated as follows: BW $(\mathrm{kg}) \times 29$ /urinary concentrations of creatinine $(\mathrm{mg} / \mathrm{L})$. Urinary mineral excretion was calculated based on the urinary volume and the concentrations of $\mathrm{Ca}$ and $\mathrm{Mg}$ in the urine samples. Apparent digestibility of $\mathrm{Ca}, \mathrm{P}$, and $\mathrm{Mg}$ were calculated based on intake of the respective minerals and fecal excretion using iNDF. Mineral retention was calculated based on intake minus fecal and urinary excretion.

\section{Statistical Analyses}

The experiment followed a randomized complete block design with cow as the experimental unit. Area under the curve (AUC) for concentration of iCa in blood and change on $\mathrm{iCa}$ relative to $\mathrm{h} 0$ of the $\mathrm{PTH}$ challenge were calculated by applying the trapezoid method using the EXPAND procedure of SAS (SAS ver. 9.4, SAS/STAT, SAS Institute Inc., Cary, NC).

The sample size was calculated based on the work of Goff et al. (2014), in which feeding an acidogenic diet increased the response in tCa to exogenous PTH by approximately $0.35 \mathrm{~m} M$ with an estimated standard deviation of $0.25 \mathrm{mM}$. Under those assumptions, and considering $\alpha$ of 0.05 and $\beta$ of 0.20 , the sample size calculated using the POWER procedure of SAS was 20 experimental units (10 per treatment).

Normality of residuals and homogeneity of variance were examined for each continuous dependent variable analyzed after fitting the statistical models. Responses that violated the assumptions of normality were subjected to power transformation according to the Box-Cox procedure (Box and Cox, 1964) using a macro for mixed models in SAS (Piepho, 2009). The least squares mean and standard error of the mean were back transformed for presentation of results according to Jørgensen and Pedersen (1998).

Continuous data were analyzed by ANOVA with the MIXED procedure of SAS. For responses with a single measurement per cow, the statistical models included the fixed effects of treatment (DCAD +200 vs. DCAD $-150 \mathrm{mEq} / \mathrm{kg}$ of $\mathrm{DM}$ ), parity (lactation 1 vs. lactation $>1$ ), and period ( 1 vs. 2 ); the interactions between treatment and parity and treatment and period; and the random effect of block. For responses with repeated measures within experimental unit, the statistical models included the fixed effects of treatment, time (hour or day), parity, and period; the interactions between treatment and time, treatment and parity, and treatment and period; and the random effects of block and of cow nested within treatment. Measurements taken on experimental d 0, before dietary treatments started, were used as covariates in the statistical models. The Repeated statement was included in all mixed models with repeated measurements within experimental unit, and time (hour or day) was specified as the effect. The covariance structure with the smallest Akaike's information criterion was chosen, and most analyses used the first-order autoregressive structure for equally spaced measurements or spatial power for unequally spaced measurements. The Kenward-Roger method was used to compute the approximate denominator degrees of freedom for the $\mathrm{F}$ tests in the statistical models. Nonsignificant $(P>0.10)$ interactions were removed from the statistical models by backward elimination. Treatment differences with $P \leq 0.05$ were considered significant, whereas tendencies for differences were reported if $0.05<P \leq 0.10$. 


\section{RESULTS}

Of the 20 cows enrolled in the experiment, 1 cow underwent parturition on experimental d 13 and was removed prematurely from the experiment. Therefore, analyses of data referent to the PTH challenge performed on experimental d 13 included 19 cows, whereas all the other analyses included all 20 cows. No adverse events were observed during the experiment. Treatment did not affect DMI, and both treatments consumed the same $11.7 \pm 0.4 \mathrm{~kg} / \mathrm{d}$. However, water intake was greater $(P=0.04)$ in cows fed DCAD -150 compared with those fed DCAD $+200(\mathrm{DCAD}+200=32.5$ vs. DCAD $-150=35.9 \pm 2.5 \mathrm{~L} / \mathrm{d})$.

\section{Blood Acid-Base Status, Urinary $\mathrm{pH}$, and Blood Chemistry}

Feeding the acidogenic diet reduced $(P<0.001)$ blood $\mathrm{pH}$, partial pressure of $\mathrm{CO}_{2}$, total $\mathrm{CO}_{2}, \mathrm{HCO}_{3}{ }^{-}$, and base excess (Table 2). Changes in acid-base balance were observed within $1 \mathrm{~d}$ after cows started to receive DCAD -150 , with a reduction in blood $\mathrm{pH}$ already observed (Figure 1A) and respiratory compensatory mechanisms activated based on the reduced blood $\mathrm{HCO}_{3}{ }^{-}$and partial pressure of $\mathrm{CO}_{2}$ (Figures $1 \mathrm{~B}$ and
1C). Basal concentrations of PTH in plasma did not differ between treatments (Table 2).

Cows fed the acidogenic diet had a 0.41-unit smaller urinary $\mathrm{pH}$ than those fed DCAD +200 , which was already observed by $9 \mathrm{~h}$ after dietary treatments started $(8.21$ vs. $7.80 \pm 0.13$; Figure $2 \mathrm{~A})$. At $15 \mathrm{~h}$, the difference between treatments increased to $1 \mathrm{pH}$ unit. By d 3 , urinary $\mathrm{pH}$ in cows fed DCAD -150 plateaued at $\mathrm{pH}$ 5.30 and remained constant throughout the remainder of the experiment (Figure 2B). Although concentrations of iCa began to increase in cows fed DCAD -150 the day after diets started, differences between treatments were observed later, between d 1 and 3 in the experiment (Figure 1D). On d 3, cows fed DCAD -150 had greater $(P=0.02)$ concentrations of $\mathrm{iCa}$ in blood compared with those fed DCAD +200 (Figure 1D). Treatment did not affect blood oxygen and concentrations of hemoglobin, glucose, $\mathrm{K}$, or Na (Table 2).

\section{PTH Challenge: Acid-Base Status and iCa}

During the PTH challenge performed on $\mathrm{d} 3$, cows fed DCAD -150 had reduced $(P<0.001)$ blood $\mathrm{pH}$, partial pressure of $\mathrm{CO}_{2}, \mathrm{HCO}_{3}^{-}$, and base excess. These measures were not affected by the administration of PTH. Similarly, urinary pH during the challenge re-

Table 2. Effect of DCAD on measures of acid-base status and blood chemistry in prepartum Holstein cows ${ }^{1}$

\begin{tabular}{|c|c|c|c|c|c|}
\hline \multirow[b]{2}{*}{ Item $^{4}$} & \multicolumn{2}{|c|}{ Treatment $^{2}$} & \multirow[b]{2}{*}{ SEM } & \multicolumn{2}{|c|}{$P$-value ${ }^{3}$} \\
\hline & DCAD +200 & DCAD -150 & & TRT & TRT $\times$ Day \\
\hline \multicolumn{6}{|l|}{ Blood gases } \\
\hline $\mathrm{pCO}_{2}, \mathrm{mmHg}$ & 41.3 & 37.7 & 0.7 & 0.004 & 0.05 \\
\hline $\mathrm{pO}_{2}, \mathrm{mmHg}$ & 38.8 & 37.9 & 1.1 & 0.61 & 0.76 \\
\hline $\mathrm{TCO}_{2}, \mathrm{~m} M$ & 28.6 & 24.0 & 0.4 & $<0.001$ & 0.03 \\
\hline $\mathrm{sO}_{2}, \%$ & 71.8 & 68.8 & 1.7 & 0.22 & 0.77 \\
\hline \multicolumn{6}{|l|}{ Blood chemistry } \\
\hline $\mathrm{pH}$ & 7.431 & 7.389 & 0.004 & $<0.001$ & 0.75 \\
\hline $\mathrm{HCO}_{3}, \mathrm{~m} M$ & 27.4 & 22.8 & 0.4 & $<0.001$ & 0.01 \\
\hline Base excess, m $M$ & 3.1 & -2.2 & 0.3 & $<0.001$ & 0.08 \\
\hline $\mathrm{Na}, \mathrm{m} M$ & 142.3 & 142.4 & 0.2 & 0.51 & 0.34 \\
\hline $\mathrm{K}, \mathrm{m} M$ & 3.64 & 3.71 & 0.04 & 0.24 & 0.35 \\
\hline $\mathrm{iCa}, \mathrm{m} M$ & 1.23 & 1.26 & 0.01 & 0.02 & 0.88 \\
\hline Change in $\mathrm{iCa}, \mathrm{m} M$ & 0.005 & 0.039 & 0.008 & 0.009 & 0.92 \\
\hline Glucose, $\mathrm{m} M$ & 3.86 & 3.82 & 0.04 & 0.36 & 0.26 \\
\hline Hematocrit, \% & 26.3 & 26.3 & 0.4 & 0.90 & 0.76 \\
\hline Hemoglobin, g/dL & 8.9 & 9.0 & 0.1 & 0.91 & 0.54 \\
\hline $\mathrm{PTH}, \mathrm{pg} / \mathrm{mL}^{5}$ & 172.5 & 229.1 & 25.0 & 0.12 & - \\
\hline
\end{tabular}

${ }^{1}$ Jugular blood sampled and analyzed on experimental d 1 and immediately before the parathyroid hormone (PTH) challenges on $\mathrm{d} 3,8$, and 13 .

${ }^{2}$ Cows were assigned to a diet containing a DCAD of $+200($ DCAD +200$)$ or $-150 \mathrm{mEq} / \mathrm{kg}$ of DM (DCAD -150) from 247 to $263 \mathrm{~d}$ of gestation.

${ }^{3} \mathrm{TRT}=$ effect of treatment $(\mathrm{DCAD}+200$ vs. $\mathrm{DCAD}-150)$; TRT $\times$ day $=$ interaction between $\mathrm{TRT}$ and day of sampling.

${ }^{4} \mathrm{pCO}_{2}=$ partial pressure of $\mathrm{CO}_{2} ; \mathrm{pO}_{2}=$ partial pressure of $\mathrm{O}_{2} ; \mathrm{TCO}_{2}=$ total dissolved $\mathrm{CO}_{2} ; \mathrm{sO}_{2}=$ saturation of $\mathrm{O}_{2}$. Change in ionized $\mathrm{Ca}(\mathrm{iCa})$ was calculated as the difference between concentration of iCa in blood measured on $\mathrm{d} 1,3,8$, and 13 , relative to $\mathrm{d} 0$.

${ }^{5}$ Concentration of PTH in plasma analyzed on d 3 immediately before the PTH challenge started. 

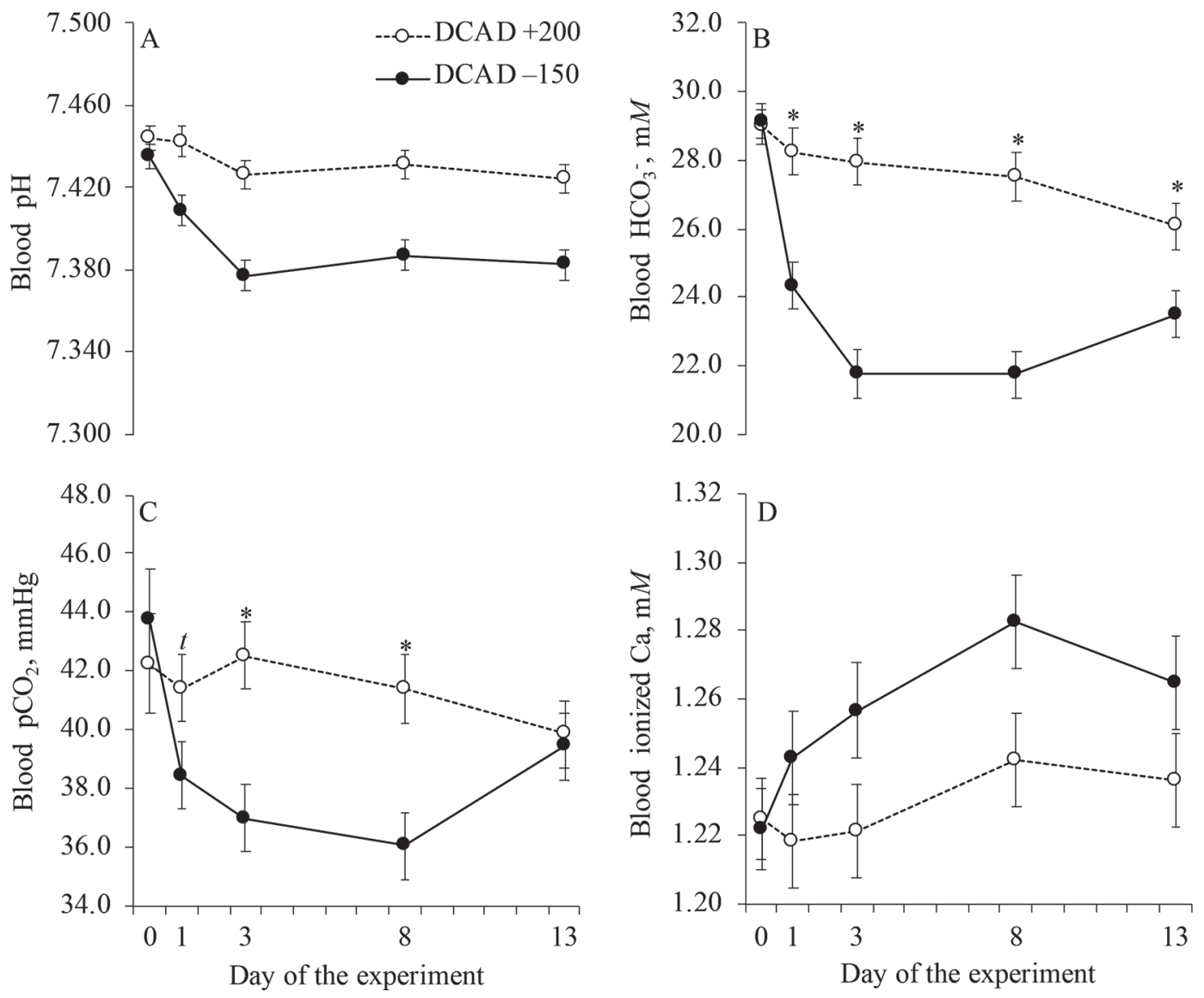

Figure 1. The $\mathrm{pH}(\mathrm{A})$, concentration of $\mathrm{HCO}_{3}^{-}(\mathrm{B})$, partial pressure of $\mathrm{CO}_{2}\left(\mathrm{pCO}_{2}\right.$; C), and concentration of ionized Ca (D) in blood of parous cows fed diets with a DCAD of +200 or $-150 \mathrm{mEq} / \mathrm{kg}$ of DM. Day 0 was a covariate in all analyses. Panel A: effects of treatment $(P<$ $0.001)$, day $(P=0.005)$, and interaction between treatment and day $(P=0.75)$. Panel B: effects of treatment $(P<0.001)$, day $(P=0.02)$, and interaction between treatment and day $(P=0.02)$. Panel C: effects of treatment $(P=0.004)$, day $(P=0.68)$, and interaction between treatment and day $(P=0.05)$. Panel D: effects of treatment $(P=0.02)$, day $(P=0.10)$, and interaction between treatment and day $(P=0.88)$. ${ }^{*}$ Within day, treatments differ $(P<0.05)$. ${ }^{t}$ Within day, treatments tended to differ $(P \leq 0.10)$. Error bars represent the SEM.

mained smaller in cows fed DCAD -150 compared with cows fed DCAD +200 , and the means were 8.11 and $6.02 \pm 0.05$ in the $44 \mathrm{~h}$ evaluated (Figure 2C); however, there was a treatment by hour interaction $(P$ $<0.001$ ). In cows fed DCAD -150 , urine $\mathrm{pH}$ increased 2 units following the PTH challenge and started to decrease once the PTH administration stopped (Figure $2 \mathrm{C}$ ). Concentrations of iCa increased (hour, $P<0.001$; Figure $3 \mathrm{~A})$ in response to $\mathrm{PTH}$, and were greater $(P=$ 0.001 ) in cows fed DCAD - 150 compared with cows fed DCAD +200 (Table 3). The concentration of blood iCa relative to the concentration immediately before the challenge had a greater $(P=0.05)$ change in cows fed DCAD -150 than in cows receiving DCAD +200 (Table 3). Cows fed DCAD -150 had a greater $(P<$ $0.001)$ ratio of $\mathrm{iCa}$ to tCa than those fed DCAD +200 (Table 3). Furthermore, the ratio of $\mathrm{iCa}$ to tCa was affected $(P<0.001)$ by hour because PTH administra- tion increased the ratio from 0.524 at $\mathrm{h} 0$ to 0.561 at h 9 relative to the beginning of the challenge. Treatment did not affect concentrations of $\mathrm{Na}$ in blood or hematocrit; however, concentrations of $\mathrm{Na}$ decreased $(P<0.001)$ with the administration of PTH from 142.9 $\mathrm{m} M$ to $140.4 \mathrm{~m} M$ in the 9-h challenge, and hematocrit decreased $(P<0.001)$ from $26.7 \%$ to $24.9 \%$ in the $9-\mathrm{h}$ challenge.

On the d 8 challenge, DCAD -150 decreased $(P$ $<0.001$ ) blood $\mathrm{pH}$, partial pressure of $\mathrm{CO}_{2}, \mathrm{HCO}_{3}^{-}$, and base excess (Table 3). Blood $\mathrm{pH}$ decreased $(P=$ 0.001 ) with PTH administration from 7.410 at $\mathrm{h} 0$ to 7.391 at $\mathrm{h} 9$ relative to the beginning of the challenge. Urinary $\mathrm{pH}$ behaved similarly relative to the challenge with PTH, as observed for d 3 (Figure 2D). Concentrations of iCa in blood increased $(P<0.001)$ with PTH administration (hour, $P<0.001$; Figure $3 \mathrm{~B}$ ), and they were greater $(P<0.001)$ in DCAD -150 than DCAD 
+200 (Table 3). Cows fed DCAD -150 had a tendency for greater $(P=0.10)$ change in blood iCa than those fed DCAD + 200 (Table 3; Figure 3E). Cows fed DCAD -150 had greater $(P=0.04)$ blood iCa to tCa ratio than those fed DCAD +200 (Table 3). Also, iCa to tCa ratio increased $(P=0.003)$ following PTH administration from 0.542 at $\mathrm{h} 0$ to 0.575 at $\mathrm{h} 9$. Concentrations of $\mathrm{Na}$ in blood were greater $(P=0.02)$ in cows fed DCAD -150 than those fed DCAD +200 (Table 3). Moreover, PTH administration reduced $(P<0.001)$ concentrations of $\mathrm{Na}$ in blood from $142.3 \mathrm{mM}$ at h 0 to 140.8 $\mathrm{m} M$ at $\mathrm{h} 18$ relative to the challenge. Blood hematocrit tended to be less $(P=0.08)$ in cows fed DCAD -150 than those fed DCAD +200 (Table 3 ), and administration of PTH reduced $(P<0.001)$ the hematocrit from $25.3 \%$ at $\mathrm{h} 0$ to $24.1 \%$ at h 9 relative to the challenge.

During the challenge on d 13, the acid-base balance responses to treatments were the same as those observed in the previous challenges (Table 3), and urinary $\mathrm{pH}$ following the challenge behaved similarly to previously observed on d 3 and 8 (Figure 2E). Concentrations of $\mathrm{iCa}$ in plasma increased in response to PTH (Figure
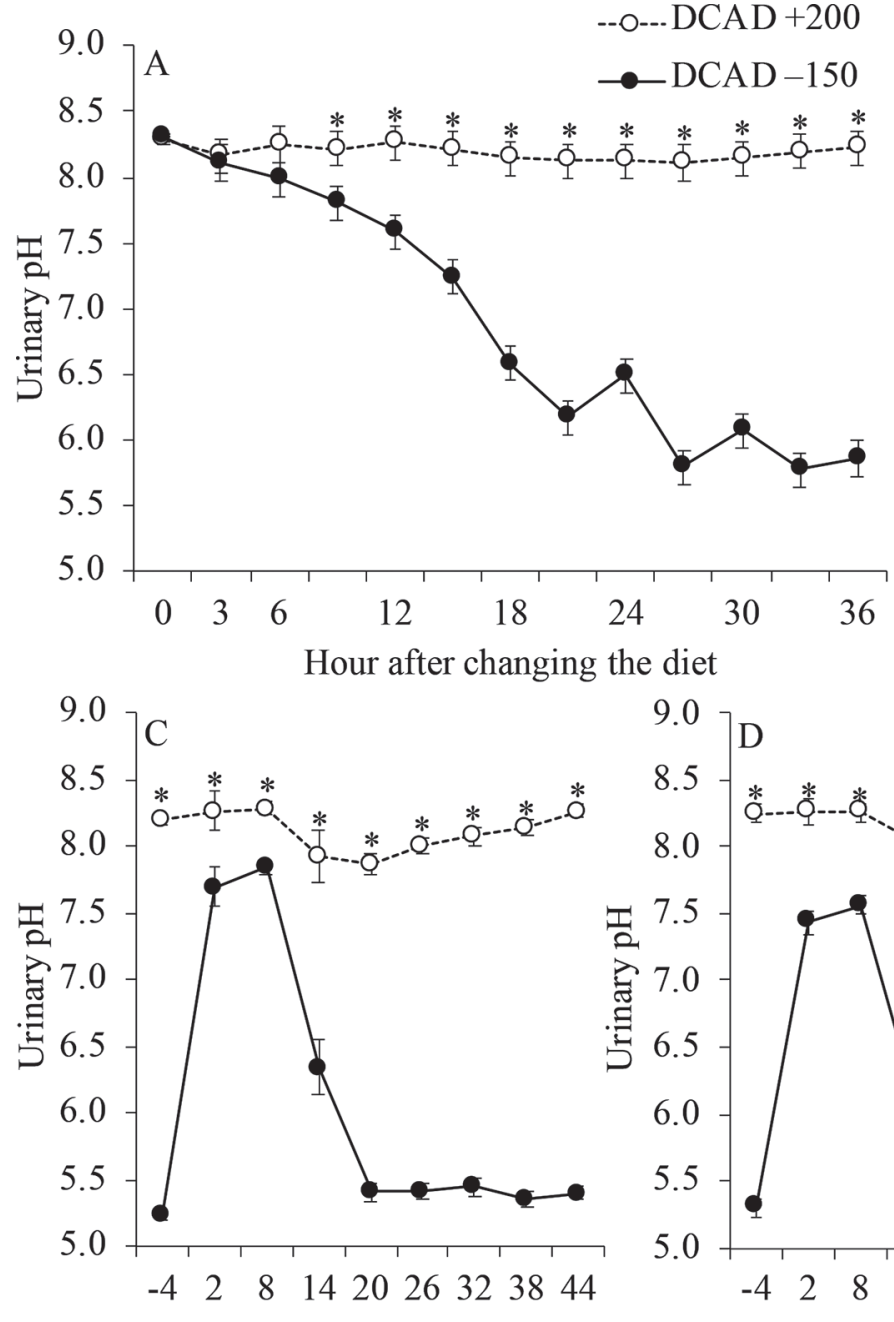

Hour relative to PTH challenge

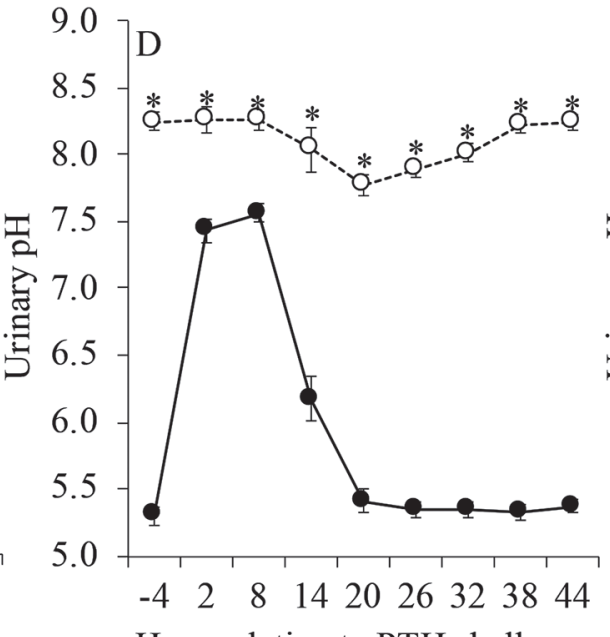

Hour relative to PTH challenge
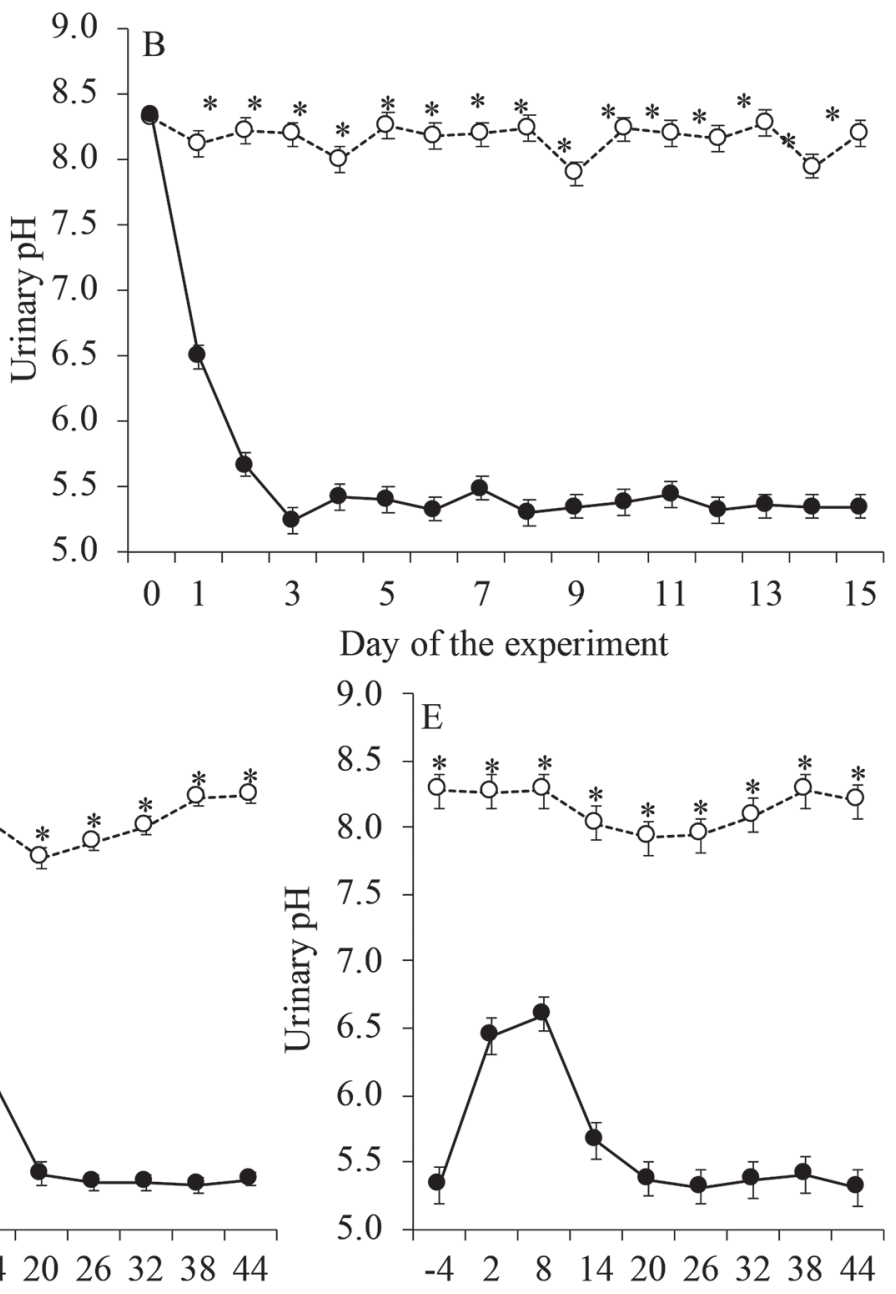

Figure 2. Urinary pH during the first $36 \mathrm{~h}$ of the experiment (A), daily during the entire experimental period (B), and in response to parathyroid hormone $(\mathrm{PTH})$ challenge on experimental d $3(\mathrm{C}), 8(\mathrm{D})$, or $13(\mathrm{E})$ in parous cows fed diets with a DCAD of +200 or $-150 \mathrm{mEq} / \mathrm{kg}$ of DM. Panel A: effects of treatment $(P<0.001)$, hour $(P<0.001)$, and interaction between treatment and hour $(P<0.001)$. Panel B: effects of treatment $(P<0.001)$, day $(P<0.001)$, and interaction between treatment and day $(P<0.001)$. Panel C: effects of treatment $(P<0.001)$, hour $(P<0.001)$, and interaction between treatment and hour $(P<0.001)$. Panel D: effects of treatment $(P<0.001)$, hour $(P<0.001)$, and interaction between treatment and hour $(P<0.001)$. Panel E: effects of treatment $(P<0.001)$, hour $(P<0.001)$, and interaction between treatment and hour $(P<0.001)$. ${ }^{*}$ Within hour or day, treatments differ $(P<0.05)$. Error bars represent the SEM. The pooled SEM for urinary $\mathrm{pH}$ during the first $36 \mathrm{~h}(\mathrm{~A})$, daily urinary $\mathrm{pH}(\mathrm{B})$, and urinary $\mathrm{pH}$ in response to PTH challenge on d 3, 8, and 13 (C-E) were $0.12,0.09,0.08$, 0.08 , and 0.13 , respectively. 
$3 \mathrm{C})$, but they were greater $(P<0.001)$ in DCAD -150 cows than DCAD +200 (Table 3 ). Cows fed DCAD -150 tended to have greater $(P=0.08)$ change in blood iCa than those fed DCAD +200 (Table 3; Figure $3 \mathrm{~F})$. The changes in concentrations in $\mathrm{iCa}$ resulted in greater $(P<0.001)$ AUC for iCa $(48.2$ vs. $50.7 \pm 0.3$ $\mathrm{mmol} / \mathrm{L} \times \mathrm{h}$; Figure $4 \mathrm{~A})$ and greater $(P=0.02)$ AUC for the increment of iCa relative to $\mathrm{h} 0$ (3.83 vs. 4.95 $\pm 0.40 \mathrm{mmol} / \mathrm{L} \times \mathrm{h}$; Figure $4 \mathrm{~B}$ ) for DCAD -150 than DCAD +200 . The ratio of iCa to tCa increased $(P$ $=0.02)$ with $\mathrm{PTH}$ administration from 0.527 at $\mathrm{h} 0$ to 0.542 at $\mathrm{h} 9$ relative to the beginning of the $\mathrm{PTH}$ challenged, but treatment did not affect $(P=0.69)$ this ratio. Administration of PTH reduced $(P<0.001)$ concentrations of $\mathrm{Na}$ in blood from $143.4 \mathrm{mM}$ at h 0 to $141.7 \mathrm{mM}$ at $\mathrm{h} 18$. It also reduced $(P<0.001)$ the hematocrit from $24.7 \%$ at $\mathrm{h} 0$ to $23.4 \%$ at h 9 relative to the beginning of the PTH challenge.
PTH Challenge: Concentrations of $t C a, t M g$, and $t P$

Administration of PTH on d 3 increased $(P<0.001)$ the concentrations of tCa. During the challenge, concentrations were greater $(P=0.05)$ in DCAD -150 than DCAD +200 (2.47 vs. $2.53 \pm 0.03 \mathrm{mM}$; Figure $5 \mathrm{~A})$. After the 9-h challenge, concentrations of tCa did not differ between treatments $(\mathrm{DCAD}+200=2.50$ vs. DCAD $-150=2.49 \pm 0.04 \mathrm{mM}$ ). Interactions between treatment and hour were observed for plasma tMg during $(P=0.03)$ and after the challenge $(P=$ $0.10)$ because DCAD +200 had greater tMg concentrations in the last hours during the challenge and the first hours after the challenge (Figure 5D). Treatment did not affect concentrations of tP in plasma during the PTH challenge $(\mathrm{DCAD}+200=1.20$ vs. DCAD $-150=1.11 \pm 0.08 \mathrm{mM})$; however, an interaction $(P$ $=0.02$ ) between treatment and hour was observed for
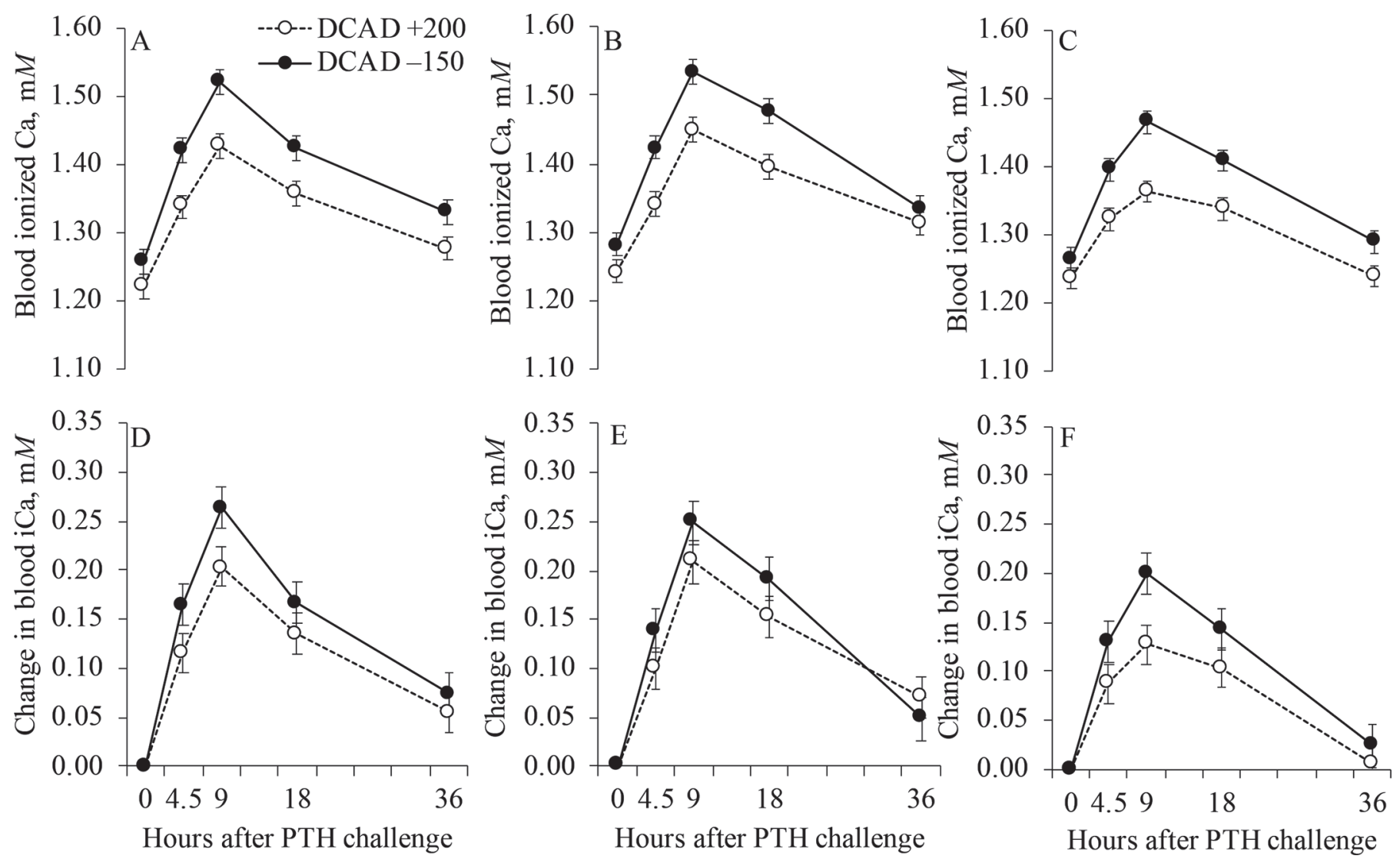

Figure 3. Concentrations of ionized Ca (iCa) in blood during a parathyroid hormone (PTH) challenge on experimental d 3 (A), 8 (B), and 13 (C), and change in blood ionized Ca relative to h 0 during a PTH challenge on experimental d 3 (D), 8 (E), and 13 (F) of parous cows fed diets with a DCAD of +200 or $-150 \mathrm{mEq} / \mathrm{kg}$ of DM. Panel A: effects of treatment $(P<0.001)$, hour $(P<0.001)$, and interaction between

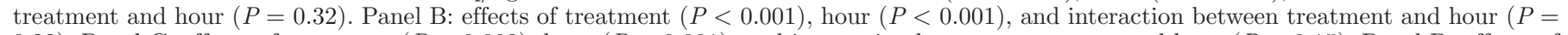

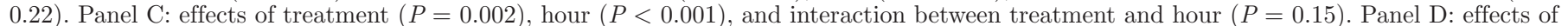

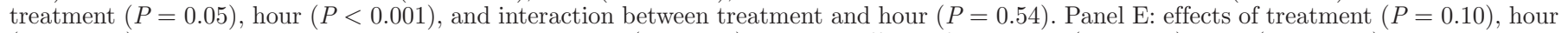

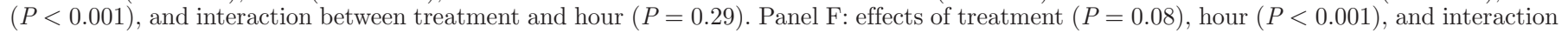
between treatment and hour $(P=0.41)$. Error bars represent the SEM. 


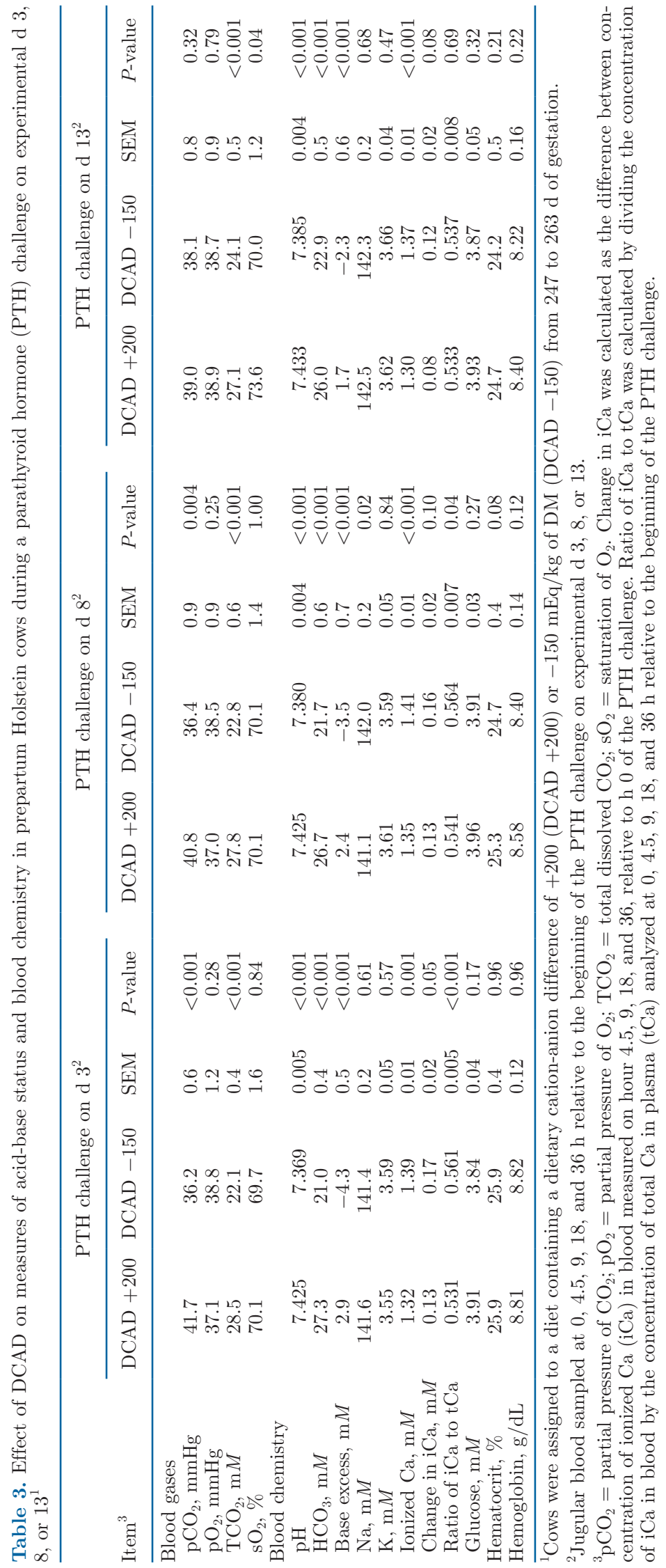


the postchallenge period because cows fed DCAD +200 had greater concentrations than those fed DCAD -150 after $24 \mathrm{~h}$ postchallenge (Figure $5 \mathrm{G}$ ).

On d 8, treatment did not affect concentrations of tCa in plasma during the challenge $(\mathrm{DCAD}+200=$
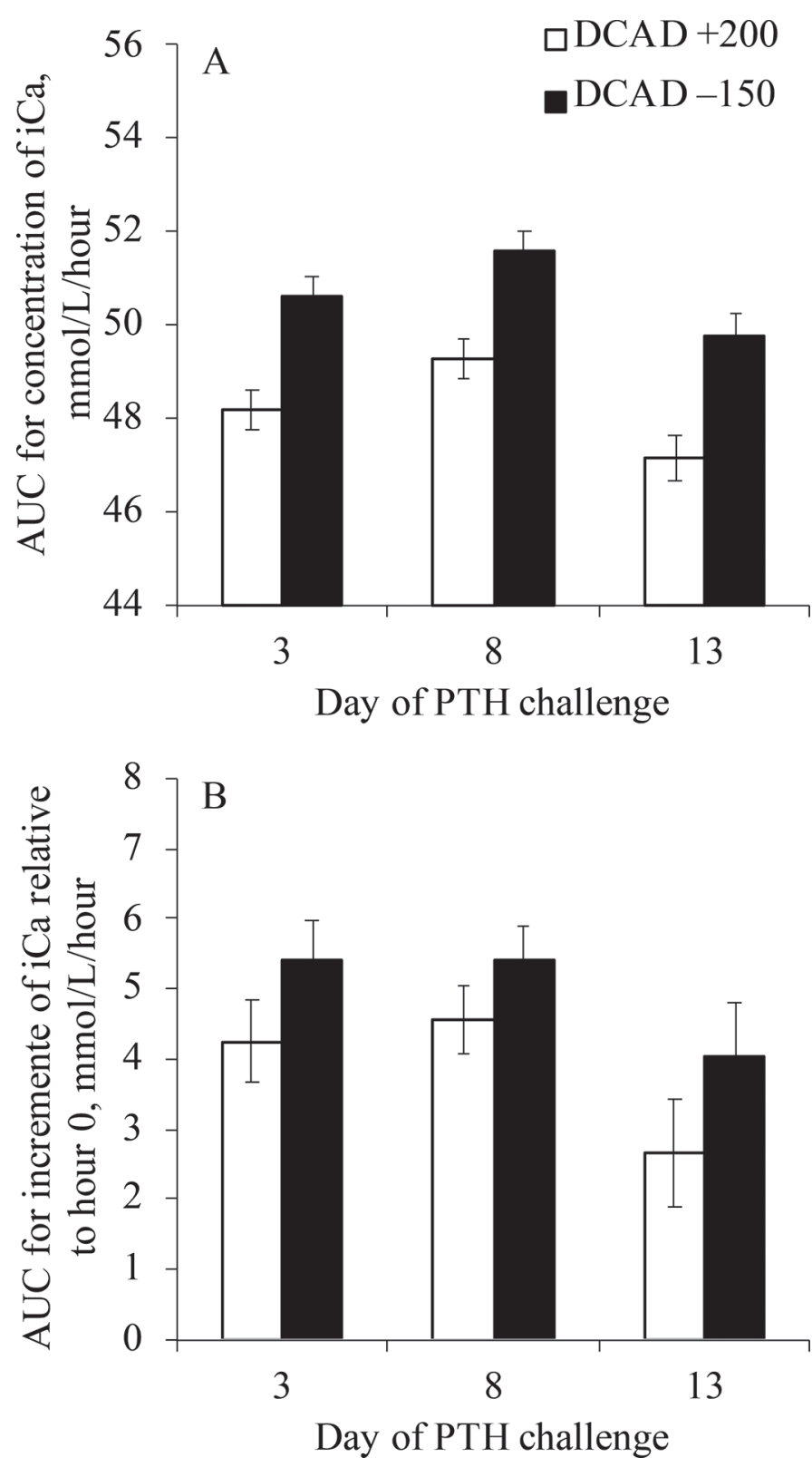

Figure 4. Area under the curve (AUC) for concentrations of ionized $\mathrm{Ca}(\mathrm{iCa})$ in blood during a parathyroid hormone (PTH) challenge (A) and for the increment of iCa relative to hour 0 during a PTH challenge (B) in parous cows fed diets with DCAD of +200 or $-150 \mathrm{mEq} /$ $\mathrm{kg}$ of DM. Panel A: effects of treatment $(P<0.001)$, challenge $(P<$ $0.001)$, and interaction between treatment and challenge $(P=0.94)$ Panel B: effects of treatment $(P=0.02)$, challenge $(P=0.04)$, and interaction between treatment and challenge $(P=0.91)$. Error bars represent the SEM. The pooled SEM were 0.43 and 0.60 in panels A and $\mathrm{B}$, respectively.
2.51 vs. $\mathrm{DCAD}-150=2.52 \pm 0.04 \mathrm{~m} M)$; however, during the postchallenge there was an interaction $(P=$ 0.003 ) between treatment and hour for plasma tCa because cows fed DCAD - 150 had greater concentrations of tCa until $18 \mathrm{~h}$, but then smaller concentrations of tCa after $24 \mathrm{~h}$ than cows fed DCAD +200 (Figure 5B). Cows fed DCAD -150 had smaller $(P=0.05)$ concentrations of $\mathrm{tMg}$ in plasma than those fed DCAD +200 during the PTH challenge (0.93 vs. $0.88 \pm 0.02 \mathrm{mM}$; Figure 5E), whereas after the challenge, concentrations did not differ between treatments $(\mathrm{DCAD}+200=0.82$ vs. DCAD $-150=0.79 \pm 0.02 \mathrm{mM}$ ). Concentrations of tP in plasma did not differ between treatments during the PTH challenge (DCAD $+200=1.29$ vs. DCAD $-150=1.17 \pm 0.08 \mathrm{~m} M$; Figure $5 \mathrm{H})$; however, a tendency $(P=0.07)$ for an interaction between treatment and hour was observed after the challenge (Figure $5 \mathrm{H}$ ).

On d 13, treatment did not affect the concentrations of tCa or tP in plasma during or after the PTH challenge (Figure 5C and 5I). There was a tendency $(P=$ $0.06)$ for an interaction between treatment and hour for concentrations of $\mathrm{Mg}$ in plasma during the PTH challenge (Figure 5F). Similarly, there was an interaction $(P<0.05)$ between treatment and hour for concentration of Mg in plasma after the PTH challenge.

\section{PTH Challenge: Concentrations of Vitamin D Metabolites and PTH}

On d 3, cows fed DCAD -150 had smaller $(P=0.04)$ concentrations of vitamin $\mathrm{D}_{3}$ in plasma than those fed DCAD $+200(\mathrm{DCAD}+200=1.79$ vs. DCAD $-150=$ $1.52 \pm 0.17 \mathrm{ng} / \mathrm{mL}$ : Figure $6 \mathrm{~A})$. In fact, there was a tendency $(P=0.06)$ for an interaction between treatment and hour because the differences between treatments increased at h 8 and 24 after the PTH challenge. Treatment did not affect concentration of 25-hydroxyvitamin $\mathrm{D}_{3}$ in plasma $(\mathrm{DCAD}+200=41.6$ vs. $\mathrm{DCAD}-150=$ $40.2 \pm 2.8 \mathrm{ng} / \mathrm{mL})$, although a tendency $(P=0.08)$ for interaction between treatment and hour was detected (Figure 6B). Concentrations of 3-epi-25-hydroxyvitamin $\mathrm{D}_{3}$ in plasma tended $(P=0.08)$ to be less in cows fed DCAD -150 than those fed DCAD + 200 (DCAD $+200=5.82$ vs. DCAD $-150=4.71 \pm 0.74 \mathrm{ng} / \mathrm{mL}$; Figure $6 \mathrm{C}$ ). The pattern of concentrations of combined 25-hydroxyvitamin $\mathrm{D}_{3}$ metabolites followed those of the individual metabolites (Figure 6D). Treatment did not affect the concentrations of 1,25-dihydroxyvitamin $\mathrm{D}_{3}$ in plasma $(\mathrm{DCAD}+200=78.0$ vs. $\mathrm{DCAD}-150=78.6$ $\pm 5.4 \mathrm{pg} / \mathrm{mL}$; Figure $6 \mathrm{E})$, but cows fed DCAD -150 had a smaller $(P=0.03)$ change in concentration of 1,25-dihydroxyvitamin $\mathrm{D}_{3}$ in plasma relative to $\mathrm{h} 0$ of the PTH challenge than those fed DCAD +200 (DCAD $+200=44.1$ vs. DCAD $-150=32.9 \pm 3.4$; Figure 
7A). Nevertheless, cows fed DCAD - 150 had a greater change in blood iCa relative to parallel changes in concentrations of 1,25-dihydroxyvitamin $\mathrm{D}_{3}$ in plasma between hours 0 and 9 of the PTH challenge (Figure $7 \mathrm{~B})$. The slope of the regression was 2.5 -fold greater for DCAD -150 than for DCAD +200 and a change in $10 \mathrm{pg} / \mathrm{mL}$ in 1,25 -dihydroxyvitamin $\mathrm{D}_{3}$. Treatment did not affect the concentrations of 24,25-dihydroxyvitamin
$\mathrm{D}_{3}$ in plasma $(\mathrm{DCAD}+200=2.22$ vs. $\mathrm{DCAD}-150=$ $2.25 \pm 0.24 \mathrm{ng} / \mathrm{mL}$; Figure $6 \mathrm{~F})$.

\section{DCAD and Mineral Balance}

On d 2, treatment did not affect apparent DM digestibility, with a mean of $66.7 \%$. Treatment did not affect intake or excretion of $\mathrm{Ca}$; however, cows fed DCAD

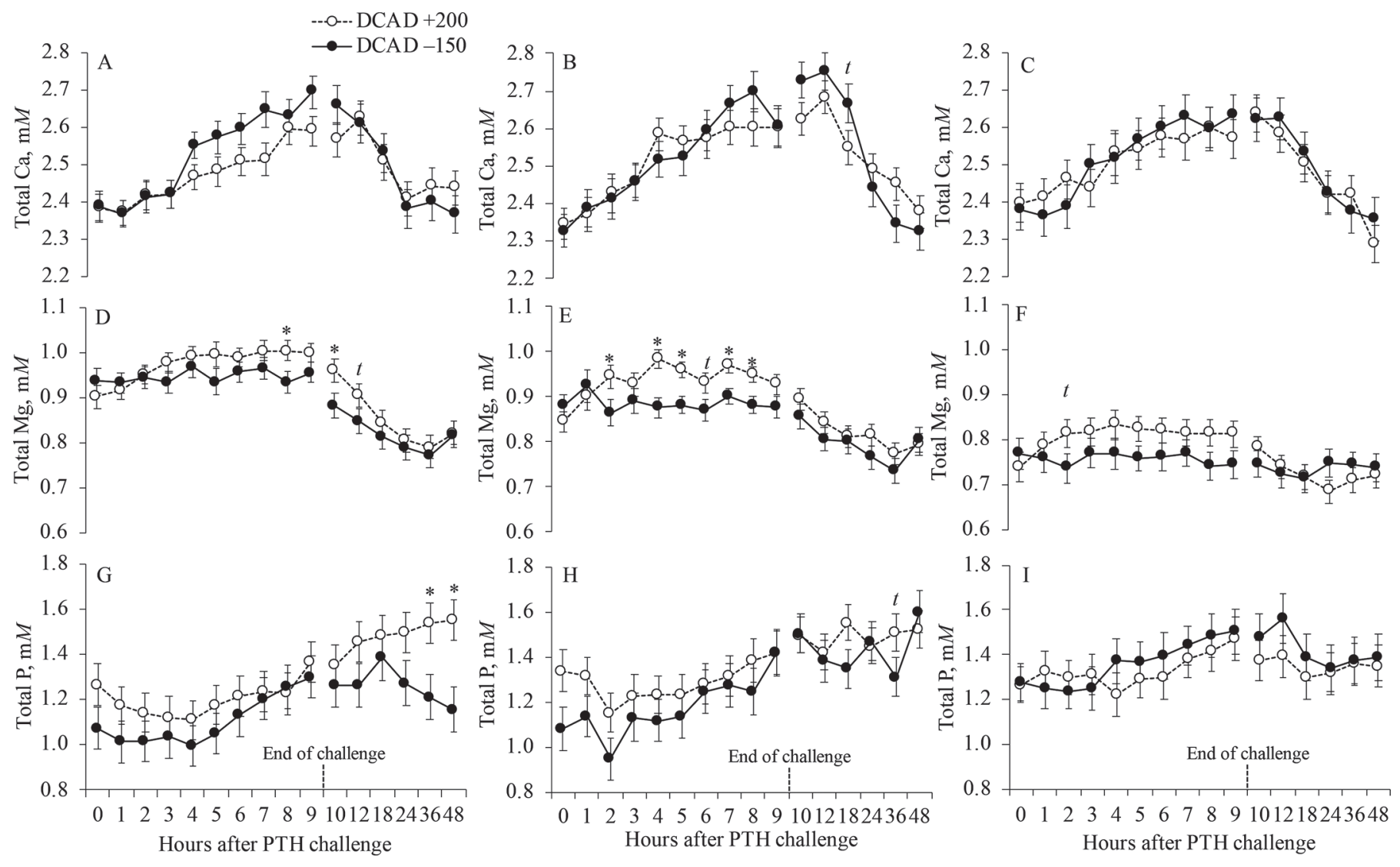

Figure 5. Concentrations of total Ca during and after a parathyroid hormone (PTH) challenge on experimental d 3 (A), 8 (B), and 13 (C); total Mg during and after a PTH challenge on experimental d 3 (D), 8 (E), and 13 (F); and total P during and after a PTH challenge on experimental d $3(\mathrm{G}), 8(\mathrm{H})$, and 13 (I) in plasma of parous cows fed diets with a DCAD of +200 or $-150 \mathrm{mEq} / \mathrm{kg}$ of DM. Panel A: challenge; effects of treatment $(P=0.05)$, hour $(P<0.001)$, and interaction between treatment and hour $(P=0.14)$; after challenge; effects of treatment $(P=0.90)$, hour $(P<0.001)$, and interaction between treatment and hour $(P=0.03)$. Panel B: challenge; effects of treatment $(P=0.93)$, hour $(P<0.001)$, and interaction between treatment and hour $(P=0.58)$; after challenge; effects of treatment $(P=0.81)$, hour $(P<0.001)$, and interaction between treatment and hour $(P=0.003)$. Panel C: challenge; effects of treatment $(P=0.91)$, hour $(P<0.001)$, and interaction between treatment and hour $(P=0.19)$; after challenge; effects of treatment $(P=0.85)$, hour $(P<0.001)$, and interaction between treatment and hour $(P=0.46)$. Panel D: challenge; effects of treatment $(P=0.37)$, hour $(P<0.001)$, and interaction between treatment and hour $(P$ $=0.03)$; after challenge; effects of treatment $(P=0.23)$, hour $(P<0.001)$, and interaction between treatment and hour $(P=0.10)$. Panel E: challenge; effects of treatment $(P=0.05)$, hour $(P=0.005)$, and interaction between treatment and hour $(P=0.05)$; after challenge; effects of treatment $(P=0.37)$, hour $(P<0.001)$, and interaction between treatment and hour $(P=0.39)$. Panel F: challenge; effects of treatment $(P=0.23)$, hour $(P=0.22)$, and interaction between treatment and hour $(P=0.06)$; after challenge; effects of treatment $(P=0.78)$, hour $(P$ $=0.03)$, and interaction between treatment and hour $(P=0.05)$. Panel G: challenge; effects of treatment $(P=0.42)$, hour $(P<0.001)$, and interaction between treatment and hour $(P=0.67)$; after challenge; effects of treatment $(P=0.08)$, hour $(P=0.25)$, and interaction between treatment and hour $(P=0.02)$. Panel H: challenge; effects of treatment $(P=0.33)$, hour $(P<0.001)$, and interaction between treatment and hour $(P=0.43)$; after challenge; effects of treatment $(P=0.57)$, hour $(P=0.08)$, and interaction between treatment and hour $(P=0.07)$. Panel I: challenge; effects of treatment $(P=0.79)$, hour $(P<0.001)$, and interaction between treatment and hour $(P=0.25)$; after challenge; effects of treatment $(P=0.55)$, hour $(P=0.18)$, and interaction between treatment and hour $(P=0.83)$. ${ }^{*}$ Within day, treatments differ $(P<0.05)$. ${ }^{t}$ Within day, treatments tended to differ $(P \leq 0.10)$. Error bars represent the SEM. The pooled SEM for the $48 \mathrm{~h}$ for total Ca on $\mathrm{d} 3,8$, and 13 were, respectively, 0.04, 0.05, and 0.05, for total $\mathrm{Mg}$ on d 3, 8, and 13 were, respectively, 0.03, 0.02, and 0.03, and for total P on d 3, 8, and 13 were, respectively, $0.09,0.09$, and 0.09 

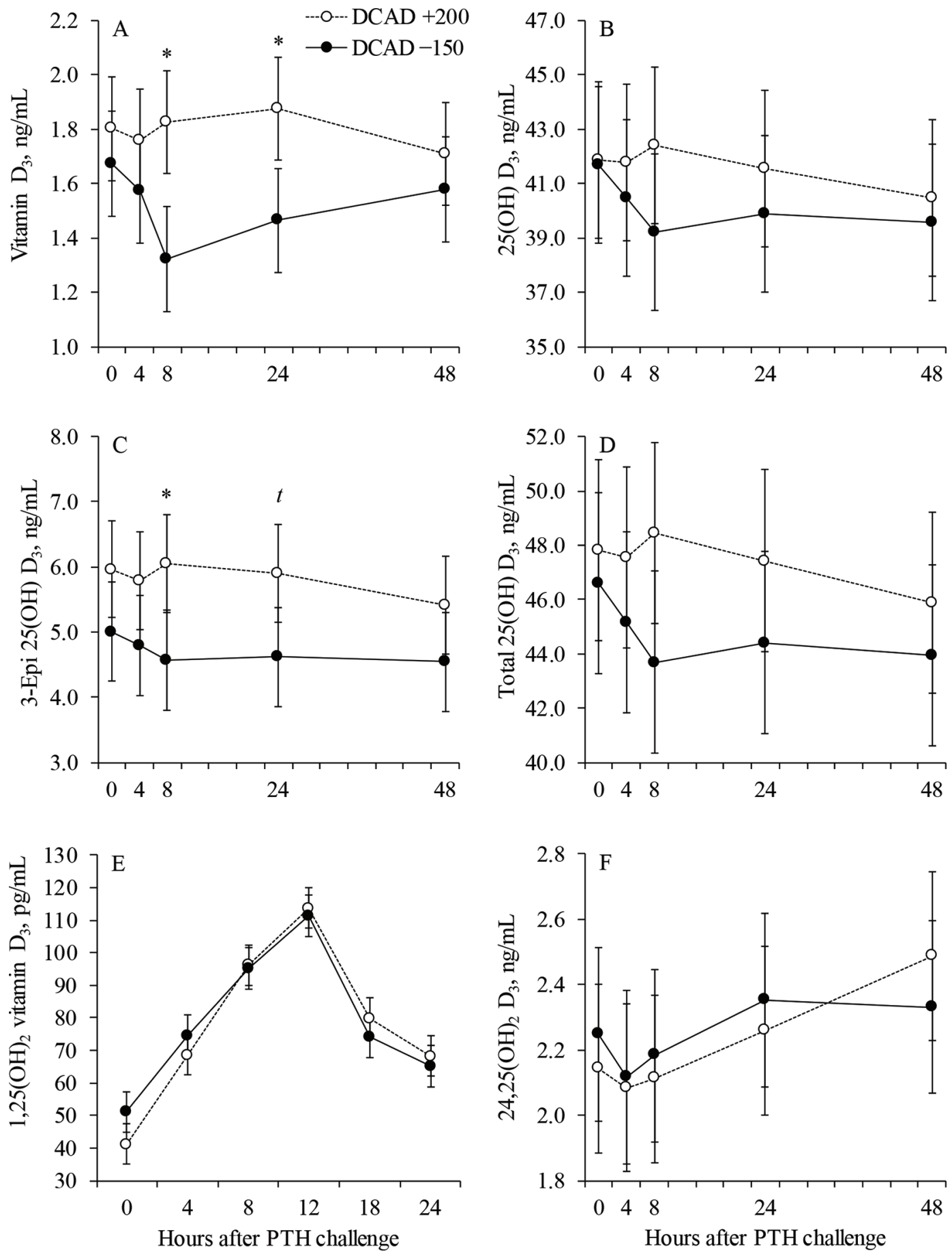

Figure 6. Concentrations of vitamin $\mathrm{D}_{3}$ (A), 25-hydroxyvitamin $\mathrm{D}_{3}$ (B), 3-epi-25-hydroxyvitamin $\mathrm{D}_{3}(\mathrm{C})$, total 25-hydroxyvitamin $\mathrm{D}_{3}$ (D), 1,25-dihydroxyvitamin $\mathrm{D}_{3}(\mathrm{E})$, and 24,25-dihydroxyvitamin $\mathrm{D}_{3}(\mathrm{~F})$ in plasma of parous cows fed diets with a DCAD of +200 or $-150 \mathrm{mEq} / \mathrm{kg}$ of DM. Panel A: effects of treatment $(P=0.04)$, hour $(P=0.34)$, and interaction between treatment and hour $(P=0.06)$. Panel B: effects of treatment $(P=0.72)$, hour $(P=0.02)$, and interaction between treatment and hour $(P=0.08)$. Panel C: effects of treatment $(P=0.08)$, hour $(P=0.12)$, and interaction between treatment and hour $(P=0.25)$. Panel D: effects of treatment $(P=0.57)$, hour $(P=0.01)$, and interaction between treatment and hour $(P=0.03)$. Panel E: effects of treatment $(P=0.92)$, hour $(P<0.001)$, and interaction between treatment and hour $(P=0.55)$. Panel F: effects of treatment $(P=0.90)$, hour $(P=0.04)$, and interaction between treatment and hour $(P=0.64) .{ }^{*}$ Within hour, treatments differ $(P<0.05)$. Error bars represent the SEM. The pooled SEM for vitamin $\mathrm{D}_{3}, 25$-hydroxyvitamin $\mathrm{D}_{3}, 3$-epi-25-hydroxyvitamin $\mathrm{D}_{3}$, total 25-hydroxyvitamin $\mathrm{D}_{3}, 1,25$-dihydroxyvitamin $\mathrm{D}_{3}$, and 24,25 -dihydroxyvitamin $\mathrm{D}_{3}$ were $0.18,2.8,0.7,3.3,5.4$, and 0.24, respectively. $\mathrm{PTH}=$ parathyroid hormone. 

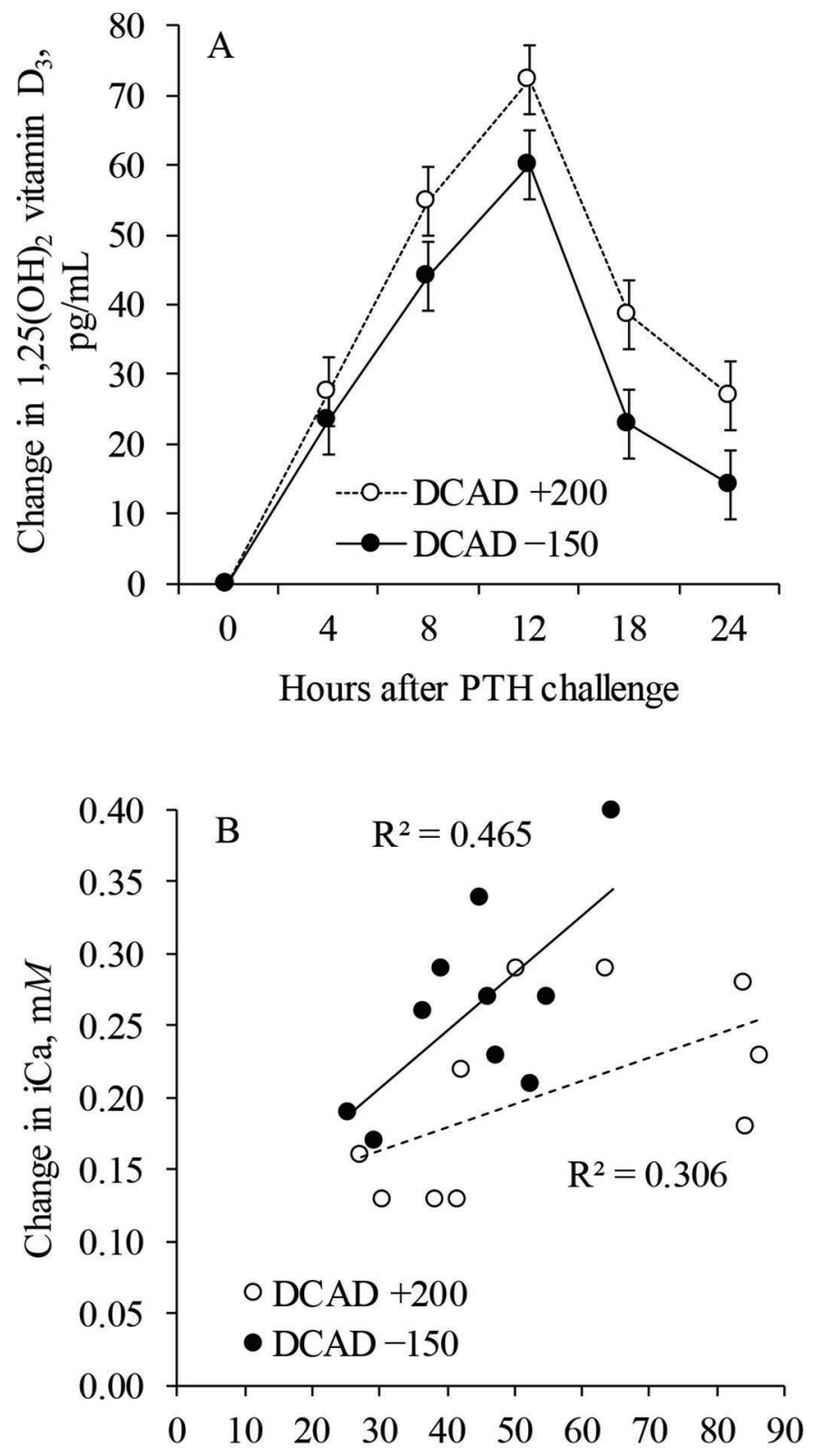

Change in $1,25(\mathrm{OH})_{2}$ vitamin $\mathrm{D}_{3}, \mathrm{pg} / \mathrm{mL}$

Figure 7. Changes in concentrations of 1,25-dihydroxyvitamin $\mathrm{D}_{3}$ in plasma relative to h 0 on experimental d 3 (A) and regression lines between the change in concentrations of ionized $\mathrm{Ca}(\mathrm{iCa})$ in blood and the change in concentrations of 1,25-dihydroxyvitamin $\mathrm{D}_{3}$ in plasma between 0 and $9 \mathrm{~h}$ relative to the start of the parathyroid hormone $(\mathrm{PTH})$ challenge $(\mathrm{B})$ in parous cows fed diets with a DCAD of +200 or $-150 \mathrm{mEq} / \mathrm{kg}$ of DM. Panel A: effects of treatment $(P=0.03)$, hour $(P<0.001)$, and interaction between treatment and hour $(P=$ $0.73)$. Panel B: change $[\mathrm{iCa}]=0.1156+0.0016 \times$ change $\left[1,25(\mathrm{OH})_{2}\right.$ vitamin $\left.\mathrm{D}_{3}\right]$ for DCAD +200 and change $[\mathrm{iCa}]=0.0872+0.0040 \times$ change $\left[1,25(\mathrm{OH})_{2}\right.$ vitamin $\left.\mathrm{D}_{3}\right]$ for DCAD -150 . Error bars in panel A represent the SEM. The pooled SEM for change in concentration 1,25-dihydroxyvitamin $\mathrm{D}_{3}$ in plasma was $3.4 \mathrm{pg} / \mathrm{mL}$.
-150 had more $(P=0.007)$ Ca absorbed in the gastrointestinal tract than those fed DCAD +200 (Table 4). Consequently, apparent digestibility of $\mathrm{Ca}$ also was greater $(P=0.004)$ in cows fed DCAD -150 than those fed DCAD +200 . Treatment affected urinary excretion of Ca that was greater $(P<0.001)$ in DCAD -150 than DCAD +200; however, the Ca retention did not differ between treatments, and cows retained almost $19 \mathrm{~g} / \mathrm{d}$ of Ca. Cows fed DCAD -150 had less $(P<$ $0.05)$ intake and fecal excretion of $\mathrm{Mg}$ (Table 4). Nevertheless, the amounts absorbed, apparent digestibility, urinary excretion, and amounts retained did not differ between treatments. Treatment did not affect any of the measures of $\mathrm{P}$ digestion (Table 4 ).

On $\mathrm{d} 7$, DCAD -150 tended $(P=0.10)$ to reduce apparent DM digestibility (Table 4 ). Similar to results on d 2, Ca intake and fecal excretion did not differ between treatments, but gastrointestinal absorption and apparent digestibility of $\mathrm{Ca}$ were both greater $(P$ $<0.05)$ in DCAD -150 than DCAD +200 (Table 4). Treatment affected urinary excretion of $\mathrm{Ca}$ that was greater $(P<0.001)$ in cows fed DCAD -150 than those fed DCAD + 200; however, treatment did not affect Ca retention, and cows retained $16.1 \mathrm{~g}$ of $\mathrm{Ca} / \mathrm{d}$. Magnesium intake and fecal excretion did not differ between dietary treatments. Although cows fed DCAD -150 had a tendency $(P=0.10)$ to have reduced absorption of $\mathrm{Mg}$ from the gastrointestinal tract compared with those fed DCAD +200, apparent digestibility of $\mathrm{Mg}$ was not affected (Table 4). Moreover, urinary Mg excretion was not affected by treatment. On the other hand, cows fed DCAD -150 had smaller $\mathrm{Mg}$ retention than those fed DCAD +200 (Table 4). Cows fed DCAD -150 tended $(P=0.07)$ to have greater $\mathrm{P}$ intake than those fed DCAD + 200; however, fecal excretion, gastrointestinal absorption, and apparent digestibility of $\mathrm{P}$ were not affected by dietary treatments (Table 4 ).

\section{DISCUSSION}

Intravenous administration of $\mathrm{PTH}$ successfully increased concentrations of $\mathrm{iCa}, \mathrm{tCa}$, and 1,25-dihydroxyvitamin $\mathrm{D}_{3}$ in dairy cows; a period of $3 \mathrm{~d}$ of exposure to the acidogenic diet was sufficient to elicit an improved tissue responsiveness to PTH based on greater changes on $\mathrm{iCa}$ and $\mathrm{tCa}$ in cows fed DCAD -150 than those fed the DCAD +200 . Furthermore, the present results demonstrated that cows under metabolic acidosis had increased gastrointestinal absorption of $\mathrm{Ca}$ that maintained a positive and similar $\mathrm{Ca}$ balance to that observed in cows fed the alkalogenic diet. Daily retentions of Ca were larger than $16 \mathrm{~g} / \mathrm{d}$, in spite of the hypercalciuria induced by the renal tubular acidosis in cows fed the DCAD -150 . 
Cows fed DCAD -150 developed metabolic acidosis within the first $24 \mathrm{~h}$ after the dietary treatments started. Additionally, compensatory mechanisms with changes in blood gases were observed concurrently. Interestingly, renal compensatory mechanisms with increased excretion of acid based on the reduced urinary $\mathrm{pH}$ were observed in the first $9 \mathrm{~h}$ of treatment in an attempt to remove the excess of $\mathrm{H}^{+}$to reestablish blood $\mathrm{pH}$ (Stewart, 1983). The increased concentration of $\mathrm{H}^{+}$ in blood competes with iCa to bind with negatively charged proteins such as albumin, thereby resulting in release of iCa from proteins that alters the ratio of $\mathrm{iCa}$ to tCa in blood, as observed in the experiment. Also, the reduced concentrations of $\mathrm{HCO}_{3}{ }^{-}$in blood results in less iCa complexed with salts, and thus results in more iCa present in blood that was previously complexed with bicarbonate salts (Oberleithner et al., 1982). Additionally, during acidosis, the PTH-vitamin D axis is more active as shown by increased secretion and half-life of PTH (Lopez et al., 2002), number of PTH receptors in bone cells (Disthabanchong et al., 2002), and tissue responsiveness to PTH (Goff et al., 2014). Osteoclast activity also is stimulated under metabolic acidosis, leading to $\mathrm{Ca}$ release from bone (Frick and Bushinsky, 2003). Collectively, metabolic acidosis increases concentrations of iCa in blood through multiple mechanisms. Interestingly, blood iCa began to increase $1 \mathrm{~d}$ after cows received the DCAD -150 diet, although differences in concentration of $\mathrm{iCa}$ between treatments only occurred between d 1 and 3 , whereas alterations in acid-base balance were observed by $24 \mathrm{~h}$. Perhaps the degree of acid-base balance disturbance with DCAD -150 observed at $24 \mathrm{~h}$ was not sufficient to elicit large changes in iCa concentrations, or that the effect of metabolic acidosis on blood iCa is time-dependent. This delay in response could have occurred because of the need to activate different cellular mechanisms, and intracellular signaling cascades involving Ca regulatory mechanisms needed to increase concentrations of $\mathrm{Ca}$ in blood.

Diet-induced metabolic acidosis has previously been reported to increase tissue responsiveness to PTH in Jersey cows (Goff et al., 2014), in which intramuscular administration of PTH every $3 \mathrm{~h}$ resulted in greater increases in concentration of tCa, 1,25-dihydroxyvitamin $\mathrm{D}_{3}$, and the bone resorption marker carboxyterminal telopeptide of type 1 collagen in plasma compared with cows fed an alkalogenic diet. In Goff et al. (2014), cows had been fed the acidogenic diet for $14 \mathrm{~d}$ before the challenge, so it was clear that 2 wk of feeding was sufficient to enhance tissue responsiveness to PTH. Here, we tested the hypothesis that responses to $\mathrm{PTH}$ are enhanced by acidogenic diets as early as $3 \mathrm{~d}$ of feeding. The rationale was that changes in acid-base balance are observed in the first 12 to $24 \mathrm{~h}$ after cows consume an acidogenic diet, and the alterations in blood $\mathrm{pH}$ and acid-base balance underlie the mechanisms for improved Ca homeostasis under metabolic acidosis. In fact, PTH-induced changes in $\mathrm{iCa}$ and tCa were greater in cows fed acidogenic diets as soon as d 3. However,

Table 4. Effect of DCAD on intake, excretion, and retention of minerals in prepartum Holstein cows ${ }^{1}$

\begin{tabular}{|c|c|c|c|c|c|c|c|c|}
\hline \multirow[b]{2}{*}{ Item } & \multicolumn{4}{|c|}{ Experimental d 2} & \multicolumn{4}{|c|}{ Experimental d 7} \\
\hline & $\mathrm{DCAD}+200$ & $\mathrm{DCAD}-150$ & SEM & $P$-value & $\mathrm{DCAD}+200$ & DCAD -150 & SEM & $P$-value \\
\hline DM apparent digestibility, \% & 66.9 & 66.4 & 1.1 & 0.62 & 66.8 & 64.6 & 1.3 & 0.10 \\
\hline \multicolumn{9}{|l|}{ Calcium } \\
\hline Intake, g/d & 82.0 & 90.3 & 5.7 & 0.32 & 73.3 & 86.3 & 5.8 & 0.13 \\
\hline Fecal excretion, g/d & 64.9 & 57.2 & 4.7 & 0.19 & 55.6 & 53.5 & 5.7 & 0.74 \\
\hline Apparent absorption, g/d & 17.1 & 33.1 & 3.7 & 0.007 & 17.7 & 32.8 & 4.3 & 0.02 \\
\hline Apparent digestibility, \% & 19.7 & 36.6 & 3.5 & 0.004 & 23.5 & 38.5 & 4.9 & 0.04 \\
\hline Urinary excretion, g/d & 1.8 & 10.8 & 0.7 & $<0.001$ & 1.8 & 16.6 & 1.1 & $<0.001$ \\
\hline Retention, g/d & 15.3 & 22.3 & 3.8 & 0.20 & 16.0 & 16.2 & 4.4 & 0.97 \\
\hline \multicolumn{9}{|l|}{ Magnesium } \\
\hline Intake, $\mathrm{g} / \mathrm{d}$ & 53.3 & 44.0 & 3.8 & 0.003 & 47.5 & 42.7 & 3.1 & 0.14 \\
\hline Fecal excretion, g/d & 33.6 & 25.3 & 2.6 & 0.04 & 29.6 & 29.9 & 3.8 & 0.93 \\
\hline Apparent absorption, g/d & 19.7 & 18.8 & 3.8 & 0.81 & 17.9 & 12.8 & 3.8 & 0.10 \\
\hline Apparent digestibility, \% & 35.1 & 39.7 & 6.5 & 0.59 & 35.8 & 29.9 & 7.9 & 0.35 \\
\hline Urinary excretion, g/d & 9.5 & 9.9 & 0.8 & 0.69 & 8.3 & 9.0 & 0.9 & 0.50 \\
\hline Retention, $\mathrm{g} / \mathrm{d}$ & 10.2 & 8.8 & 3.9 & 0.74 & 9.6 & 3.7 & 4.1 & 0.05 \\
\hline \multicolumn{9}{|l|}{ Phosphorus } \\
\hline Intake, g/d & 37.8 & 39.3 & 2.2 & 0.34 & 32.4 & 37.2 & 2.2 & 0.07 \\
\hline Fecal excretion, $\mathrm{g} / \mathrm{d}$ & 25.2 & 27.3 & 2.4 & 0.42 & 25.0 & 29.3 & 2.8 & 0.18 \\
\hline Apparent absorption, g/d & 12.7 & 12.1 & 1.4 & 0.75 & 7.4 & 8.0 & 1.7 & 0.81 \\
\hline Apparent digestibility, \% & 34.8 & 30.9 & 3.9 & 0.47 & 22.2 & 22.6 & 5.1 & 0.96 \\
\hline
\end{tabular}

${ }^{1}$ Cows were assigned to a diet containing a dietary cation-anion difference of +200 (DCAD +200) or $-150 \mathrm{mEq} / \mathrm{kg}$ of DM (DCAD -150) from 247 to 263 d of gestation. 
the current data do not imply that $3 \mathrm{~d}$ of feeding are sufficient to elicit all the benefits of feeding acidogenic diets on postpartum performance in dairy cows (Santos et al., 2019). Observational studies have shown that at least $3 \mathrm{wk}$ were needed to optimize yields of milk, fat, and protein in response to transition diets (Degaris et al., 2008). Furthermore, gestation length in dairy cows is variable, with a standard deviation of $6 \mathrm{~d}$ (VieiraNeto et al., 2017b); therefore, the recommendation of feeding acidogenic diets for $21 \mathrm{~d}$ remains.

Administration of PTH to dairy cows resulted in a greater increase in 1,25-dihydroxyvitamin $\mathrm{D}_{3}$ in Jersey cows fed a diet with $-181 \mathrm{mEq} / \mathrm{kg}$ compared with those fed a diet with $+188 \mathrm{mEq} / \mathrm{kg}$ for $14 \mathrm{~d}$ (Goff et al., 2014). The authors suggested that the concentrations of 1,25-dihydroxyvitamin $\mathrm{D}_{3}$ in response to PTH in cows fed the acidogenic diet were enhanced because metabolic acidosis increases the ability of PTH to stimulate protein expression and activity of renal $1 \alpha$-hydroxylase, and consequently increases the synthesis of 1,25-dihydroxyvitamin $\mathrm{D}_{3}$ (Goff et al., 2014). Unexpectedly, DCAD -150 did not increase the concentrations of 1,25-dihydroxyvitamin $\mathrm{D}_{3}$ compared with $\mathrm{DCAD}+200$ after the PTH challenge. In the work of Goff et al. (2014), differences between treatments with increased concentrations of 1,25-dihydroxyvitamin $\mathrm{D}_{3}$ in cows fed the acidogenic diet were only observed after $12 \mathrm{~h}$ in treatment, and PTH was administered with an initial dose of $5 \mathrm{mg}$ and then followed by sequential treatments with $3.3 \mathrm{mg}$ every $3 \mathrm{~h}$ up to $48 \mathrm{~h}$. In the present experiment, cows received a smaller amount of PTH in pulses every $20 \mathrm{~min}$ that lasted $9 \mathrm{~h}$ in an attempt to mimic the endogenous pulses from the parathyroid glands. For a cow weighing $680 \mathrm{~kg}$, the amount of PTH administered in a period of $3 \mathrm{~h}$ was only $0.34 \mathrm{mg}$, which was $11 \%$ of the dose administered by Goff et al. (2014) in Jersey cows of lighter BW. Therefore, it is possible that the PTH dose, which was administered in pulses to resemble a more physiological pattern (Samuels et al., 1993; Yamashita et al., 2003), was under regulatory mechanisms involved in maintaining concentrations of $\mathrm{Ca}$ in blood that prevented exacerbated increases in $\mathrm{iCa}$, tCa, and 1,25-dihydroxyvitamin $\mathrm{D}_{3}$. On the other hand, a challenge of longer duration with a larger dose of PTH, such as that of Goff et al. (2014), was potent enough to override the regulatory mechanisms, which resulted in an overstimulated synthesis of hormones involved in Ca homeostasis such as 1,25-dihydroxyvitamin $\mathrm{D}_{3}$. Another possibility is that the endocrine regulation of the PTH-vitamin D axis differs between breeds, and Jersey cows may respond differently to PTH compared with Holsteins. It is well documented that Jersey cows have increased susceptibility to hypocalcemia at the onset of lactation when compared with Holstein cows and may be more sensitive to the effects of PTH, stimulating increases in synthesis of 1,25-dihydroxyvitamin $\mathrm{D}_{3}$ and of Ca concentrations in blood. Finally, an important factor is that administration of PTH stopped at $9 \mathrm{~h}$; therefore, it is possible that the length of the challenge was not sufficient to elicit genomic effects on renal $1 \alpha$-hydroxylase.

It is worth noting that cows fed the acidogenic diet had a greater change in iCa, with a smaller change in 1,25-dihydroxyvitamin $\mathrm{D}_{3}$ relative to $\mathrm{h} 0$ based on the slopes observed for cows fed the acidogenic diet compared with the alkalogenic diet (Figure 7B). Blood concentration of vitamin D metabolites are tightly regulated, and 1,25-dihydroxyvitamin $\mathrm{D}_{3}$ activates transcription of the CYP24A1 gene that encodes for 24-hydroxylase protein (Ohyama et al., 1994), which increases the catabolism of 1,25-dihydroxyvitamin $\mathrm{D}_{3}$ to inactive metabolites to prevent hypercalcemia. In the current experiment, cows fed the acidogenic diet tended to have greater $(P=0.06)$ concentrations of 1,25-dihydroxyvitamin $\mathrm{D}_{3}$ before starting the $\mathrm{PTH}$ challenge compared with cows fed the alkalogenic diet $(\mathrm{DCAD}+200=41.3$ vs. $\mathrm{DCAD}-150=51.1 \pm 4.8$ $\mathrm{ng} / \mathrm{mL})$. It is possible that increased concentrations of 1,25-dihydroxyvitamin $\mathrm{D}_{3}$ might have upregulated the vitamin $\mathrm{D}$ catabolic pathways in cows fed acidogenic diets, which would limit the increase in 1,25-dihydroxyvitamin $\mathrm{D}_{3}$ after the PTH challenge started. Changes in inactivation of 1,25-dihydroxyvitamin $\mathrm{D}_{3}$ are unlikely to reflect in changes in concentrations of 24,25-dihydroxyvitamin $\mathrm{D}_{3}$ between treatments because most 24,25-dihydroxyvitamin $\mathrm{D}_{3}$ originates from the catabolism of 25-hydroxyvitamin $\mathrm{D}_{3}$ rather than 1,25-dihydroxyvitamin $\mathrm{D}_{3}$. In addition, there was some indication in the present experiment that concentrations of PTH might increase in cows fed the acidogenic compared with the alkalogenic diet, which agrees with the observation of increased synthesis of PTH in dogs under metabolic acidosis in a study by Lopez et al. (2002). Therefore, the greater concentration of PTH potentially increased the expression of $1 \alpha$-hydroxylase, resulting in greater synthesis of 1,25-dihydroxyvitamin $\mathrm{D}_{3}$ before the challenge, which would activate the vitamin D catabolic pathways through the 24 -hydroxylases (Ohyama et al., 1994).

Alternatively, little is known about the effects of metabolic acidosis on vitamin $\mathrm{D}$ carriers and tissue responses to 1,25-dihydroxyvitamin $\mathrm{D}_{3}$. Diet-induced metabolic acidosis has been reported to increase tissue protein catabolism and decrease protein synthesis in rats (Šafránek et al., 2003). In blood, most vitamin D metabolites are transported primarily bound to vitamin $\mathrm{D}$-binding protein and, to a lesser extent, to albumin (Bikle and Schwartz, 2019). In humans, only 
$0.4 \%$ of the 1,25 -dihydroxyvitamin $\mathrm{D}_{3}$ and $0.03 \%$ of the 25-hydroxyvitamin $\mathrm{D}_{3}$ are in the free form in serum (Bikle and Schwartz, 2019). The free fraction of 1,25-dihydroxyvitamin $\mathrm{D}_{3}$ is able to enter cells and interact with the vitamin D receptor (Haussler et al., 2013), whereas the bound fraction stays circulating in blood (Bikle and Schwartz, 2019). Therefore, it is possible that, although concentration of total 1,25-dihydroxyvitamin $\mathrm{D}_{3}$ did not differ between treatments, the free fraction of 1,25-dihydroxyvitamin $\mathrm{D}_{3}$ might have been different and increased in cows fed the acidogenic diet. This would result in increased stimulus of the vitamin $\mathrm{D}$ receptor, and thus explain the greater increase in blood iCa and plasma tCa in cows fed DCAD -150 than those fed DCAD +200. It is hypothesized that metabolic acidosis may increase circulating vitamin D catabolism and decrease circulating protein carriers; therefore, in addition to the increased tissue responsiveness to PTH, metabolic acidosis may presumably increase 1,25-dihydroxyvitamin $\mathrm{D}_{3}$ bioavailability and action.

During the PTH challenge, urinary $\mathrm{pH}$ increased by 2 $\mathrm{pH}$ units within $2 \mathrm{~h}$ on experimental $\mathrm{d} 3$ and 8 , and by $1 \mathrm{pH}$ unit on experimental d 13. Previous reports demonstrated that PTH does not affect $\mathrm{H}^{+}$excretion in the urine, but it increases the excretion of $\mathrm{HCO}_{3}{ }^{-}$, resulting in alkalinization of the urine (Arruda et al., 1977). Likewise, tubular phosphate reabsorption is inhibited by PTH, leading to phosphaturia (Agus et al., 1971). Phosphaturia enhances the buffering capacity of the urine and prevents a reduction in $\mathrm{pH}$. Those actions of PTH prevent accumulation of phosphate and $\mathrm{HCO}_{3}{ }^{-}$in the extracellular fluids, and thus facilitate the ionization of Ca present in blood. Therefore, these mechanisms of altered ion excretion in the urine attempt to enhance iCa promptly, while other calciotropic actions of PTH are ongoing, such as bone remodeling and synthesis of 1,25-dihydroxyvitamin $\mathrm{D}_{3}$ (Fraser and Kodicek, 1973).

Excretion of $\mathrm{Ca}$ in the urine increases during metabolic acidosis, resulting in losses greater than $6 \mathrm{~g} / \mathrm{d}$ (Rodney et al., 2018). Increased urinary Ca losses have been demonstrated in rabbits, in which tubular acidosis causes inhibition of renal $\mathrm{Ca}$ reabsorption by the $\mathrm{Ca}$ channel transient receptor potential vanilloid type 5 (Yeh et al., 2003). In the rabbit, protons in the urine sensitize Ca-channels in part by specific constitutive AA in the voltage channels that increase sensitivity to $\mathrm{pH}$ (Yeh et al., 2003). In fact, both $\mathrm{H}^{+}$and iCa present in the filtrate in the distal convoluted tubule inhibit the ability of the $\mathrm{Ca}$ channel transient receptor potential vanilloid type 5 to reabsorb $\mathrm{Ca}$, resulting in hypercalciuria (Woudenberg-Vrenken et al., 2009). In dairy cows, acidogenic diets increase urinary Ca losses by several fold compared with alkalogenic diets (Goff et al., 2014;
Rodney et al., 2018). This hypercalciuria has been thought to alter Ca balance, thereby priming bone resorption and intestinal Ca absorption for the increased Ca demands with the onset of lactation (Schonewille et al., 1999). The current findings demonstrated that metabolic acidosis induced by DCAD -150 increased apparent $\mathrm{Ca}$ absorption from the gastrointestinal tract, which compensated the increased irreversible loss in urine and maintained a positive Ca balance with $\mathrm{Ca}$ retentions larger than $15 \mathrm{~g} / \mathrm{d}$, irrespective of dietary treatment. Such amounts of Ca retained are greater than the $10.3 \mathrm{~g} / \mathrm{d}$ needed for gravid uterus accretion in a Holstein cow in the last week of gestation (House and Bell, 1993), allowing for deposition in other tissues. Lomba et al. (1978) reported a negative association between Ca absorption and DCAD in nonlactating and lactating dairy cows (i.e., as the DCAD decreased, Ca absorption increased). In agreement, in vitro experiments using an Ussing chamber with rumen epithelia from sheep fed diets differing in DCAD reported increased mucosal to serosa Ca flux in those epithelia from sheep fed acidogenic compared with alkalogenic diets (Wilkens et al., 2016). Thus, acidogenic diets increase the whole-body Ca flux (Takagi and Block, 1991), including an increase in gastrointestinal tract digestibility of $\mathrm{Ca}$ to maintain Ca homeostasis.

The 1,25-dihydroxyvitamin $\mathrm{D}_{3}$ is a potent calciotropic hormone in dairy cows (Vieira-Neto et al., 2017a). Regulation of Ca homeostasis by 1,25-dihydroxyvitamin $\mathrm{D}_{3}$ requires binding to the vitamin $\mathrm{D}$ receptor, a nuclear receptor that recognizes specific DNA sequences in vitamin D responsive elements (Haussler et al., 2013). In nonruminants, the actions of 1,25-dihydroxyvitamin $\mathrm{D}_{3}$ in the duodenum are well described to enhance the expression of the apical membrane Ca transporter, transient receptor potential cation channels vanilloid 6 (Van Cromphaut et al., 2001), the basolateral Ca transporters, plasma membrane Ca ATPase, and sodium Ca exchanger type 1 (Khuituan et al., 2013; Lee et al., 2015). In dairy cows, transcripts for vitamin $D$ receptor, calbindin- $\mathrm{d}_{9 \mathrm{k}}$, and plasma membrane Ca ATPase have been reported in the duodenum (Yamagishi et al., 2006). Therefore, it seems plausible that 1,25-dihydroxyvitamin $\mathrm{D}_{3}$ can regulate Ca absorption in the small intestine, perhaps similarly to nonruminant. Nevertheless, most Ca absorption in bovine takes place preduodenum (Khorasani and Armstrong, 1992). Further, in vitro experiments demonstrate the presence of transcellular transport of $\mathrm{Ca}$ in the bovine ruminal epithelia (Schröder et al., 2015). In sheep, acidogenic diets increased the flux of $\mathrm{Ca}$ from the mucosal to the serosal side of the ruminal epithelia (Wilkens et al., 2016), supporting increased rumen transport of Ca under metabolic acidosis. In dairy cows, oral adminis- 
tration of strontium chloride, a marker used to study Ca absorption, showed an abrupt and faster increase in plasma strontium concentration compared with abomasal dosing (Hyde et al., 2019), thereby emphasizing the importance of the rumen in $\mathrm{Ca}$ absorption in bovine. Thus, the increased apparent Ca digestibility observed in the current experiment may be a combination of 1,25-dihydroxyvitamin $\mathrm{D}_{3}$ regulating Ca absorption in the rumen, and possibly the small intestine. It is also possible that changes in acid-base balance might affect Ca transport across the gastrointestinal epithelium through mechanisms independent on vitamin $\mathrm{D}$, such as those mediated by steroids or IGF1 (Fleet and Schoch, 2010). Yet, the mechanism of how $\mathrm{Ca}$ is absorbed in the bovine gastrointestinal tract and the effects of acid-base balance on site-specific regulatory mechanisms warrant further investigation.

\section{CONCLUSIONS}

Intravenous administration of PTH at $0.05 \mu \mathrm{g} / \mathrm{kg}$ of $\mathrm{BW}$ at 20 min interval during $9 \mathrm{~h}$ to model PTH effects on Ca metabolism resulted in increases in concentrations of $\mathrm{iCa}$ and tCa and stimulated 1,25-dihydroxyvitamin $\mathrm{D}_{3}$ synthesis to concentrations similar to those observed in cows at calving. Diet-induced metabolic acidosis was observed within $24 \mathrm{~h}$ after dietary treatments started, and increases in concentration of $\mathrm{iCa}$ in blood in cows fed the acidogenic diet started $1 \mathrm{~d}$ after treatments were initiated and differed from cows fed the alkalogenic diet as soon as experimental d 3 . The results indicate that $3 \mathrm{~d}$ of offering acidogenic diets was able to elicit greater tissue responsiveness to PTH by increasing concentrations of $\mathrm{iCa}$ in blood and concentration of tCa in plasma. In spite of that, treatment did not affect the concentrations of 1,25-dihydroxyvitamin $\mathrm{D}_{3}$ in plasma during the PTH challenge. The role of acidogenic diets on bioavailability and activity of 1,25-dihydroxyvitmain $\mathrm{D}_{3}$ remains unclear from the results of the present experiment. Diet-induced metabolic acidosis resulted in hypercalciuria concurrent with increased gastrointestinal apparent absorption of $\mathrm{Ca}$ compared with cows fed the alkalogenic diet, resulting in similar and positive daily balance of $\mathrm{Ca}$ with retentions of at least $15 \mathrm{~g} / \mathrm{d}$.

\section{ACKNOWLEDGMENTS}

The authors thank Todd Pritchard, Brad Dicks, and Jesse Hooten of the University of Florida Dairy Unit for the assistance and help with facilities and animal management during the experiment. The assistance of Juan Bollatti, Kleves V. Almeida, and Angel Revilla Ruiz from the University of Florida during sample collection and processing is appreciated. The authors thank Arm and Hammer Animal and Food Production (Princeton, NJ) for providing BioChlor and sodium bicarbonate; Landus Cooperative (Ames, IA) for providing SoyPlus; and Balchem Animal Nutrition and Health (New Hampton, NY) for providing ReaShure for this experiment. Partial financial support was provided by a grant from the Southeast Milk Inc. Milk Check-off Program (Belleview, FL). The authors have not stated any conflicts of interest.

\section{REFERENCES}

Abu Damir, H., M. Phillippo, B. H. Thorp, J. S. Milne, L. Dick, and I. M. Nevison. 1994. Effects of dietary acidity on calcium balance and mobilization, bone morphology and 1,25 dihydroxyvitamin D in prepartal dairy cows. Res. Vet. Sci. 56:310-318. https://doi.org/ 10.1016/0034-5288(94)90147-3.

Agus, Z. S., J. B. Puschett, D. Senesky, and M. Goldberg. 1971. Mode of action of parathyroid hormone and cyclic adenosine $3^{\prime}, 5^{\prime}$-monophosphate on renal tubular phosphate reabsorption in the dog. J. Clin. Invest. 50:617-626. https://doi.org/10.1172/JCI106532.

AOAC Internatinoal. 2000. Official Methods of Analysis, 17th ed. Assoc. Off. Anal. Chem., Gaithersburg, MD.

Arruda, J. A. L., L. Nascimento, C. Westenfelder, and N. A. Kurtzman. 1977. Effect of parathyroid hormone on urinary acidification. Am. J. Physiol. 232:F429-F433. https://doi.org/10.1152/ajprenal .1977.232.5.F429.

Bikle, D. D., and J. Schwartz. 2019. Vitamin D binding protein, total and free vitamin D levels in different physiological and pathophysiological conditions. Front. Endocrinol. (Lausanne) 10:317. https:// doi.org/10.3389/fendo.2019.00317.

Block, E. 1984. Manipulating dietary anions and cations for prepartum dairy cows to reduce incidence of milk fever. J. Dairy Sci. 67:29392948. https://doi.org/10.3168/jds.S0022-0302(84)81657-4.

Box, G. E. P., and D. R. Cox. 1964. An analysis of transformations. J. R. Stat. Soc. B 26:211-252.

Conigrave, A. D. 2016. The calcium-sensing receptor and the parathyroid: Past, present, future. Front. Physiol. 7:563. https://doi.org/ 10.3389/fphys.2016.00563.

Degaris, P. J., I. J. Lean, A. R. Rabiee, and C. Heuer. 2008. Effects of increasing days of exposure to prepartum transition diets on milk production and milk composition in dairy cows. Aust. Vet. J. 86:341-351. https://doi.org/10.1111/j.1751-0813.2008.00335.x.

Disthabanchong, S., K. J. Martin, C. L. McConkey, and E. A. Gonzalez. 2002. Metabolic acidosis up-regulates PTH/PTHrP receptors in UMR 106-01 osteoblast-like cells. Kidney Int. 62:1171-1177. https://doi.org/10.1111/j.1523-1755.2002.kid568.x.

Ender, F., I. W. Dishington, and A. Helgebostad. 1971. Calcium balance studies in dairy cows under experimental induction and prevention of hypocalcaemic paresis puerperalis. Z. Tierphysiol. Tierernahr. Futtermittelkd. 28:233-256. https://doi.org/10.1111/ j.1439-0396.1971.tb01573.x.

Fleet, J. C., and R. D. Schoch. 2010. Molecular mechanisms for regulation of intestinal calcium absorption by vitamin $\mathrm{D}$ and other factors. Crit. Rev. Clin. Lab. Sci. 47:181-195. https://doi.org/10 .3109/10408363.2010.536429.

Fraser, D. R., and E. Kodicek. 1973. Regulation of 25-hydroxycholecalciferol-1-hydroxylase activity in kidney by parathyroid hormone. Nat. New Biol. 241:163-166. https://doi.org/10.1038/ newbio241163a0.

Frick, K. K., and D. A. Bushinsky. 2003. Metabolic acidosis stimulates RANKL RNA expression in bone through a cyclo-oxygenasedependent mechanism. J. Bone Miner. Res. 18:1317-1325. https:/ /doi.org/10.1359/jbmr.2003.18.7.1317.

Fu, Q., R. L. Jilka, S. C. Manolagas, and C. A. O'Brien. 2002. Parathyroid hormone stimulates receptor activator of NFkB ligand and 
inhibits osteoprotegerin expression via protein kinase A activation of cAMP-response element-binding protein. J. Biol. Chem. 277:48868-48875. https://doi.org/10.1074/jbc.M208494200.

Goff, J. P., A. Liesegang, and R. L. Horst. 2014. Died-induced pseudohypoparathyroidism: A hypocalcemia and milk fever risk factor. J. Dairy Sci. 97:1520-1528. https://doi.org/10.3168/jds.2013-7467.

Haussler, M. R., G. K. Whitfield, I. Kaneko, C. A. Haussler, D. Hsieh, J. Hsieh, and P. W. Jurutka. 2013. Molecular mechanisms of vitamin D action. Calcif. Tissue Int. 92:77-98. https://doi.org/10 $.1007 / \mathrm{s} 00223-012-9619-0$

House, W. A., and A. W. Bell. 1993. Mineral accretion in the fetus and adnexa during late gestation in Holstein cows. J. Dairy Sci. 76:2999-3010. https://doi.org/10.3168/jds.S0022-0302(93)77639 $-0$.

Huhtanen, P., K. Kaustell, and S. Jaakkola. 1994. The use of internal markers to predict total digestibility and duodenal flow of nutrients in cattle given six different diets. Anim. Feed Sci. Technol. 48:211-227. https://doi.org/10.1016/0377-8401(94)90173-2.

Hyde, M. L., M. R. Wilkens, and D. R. Fraser. 2019. In vivo measurement of strontium absorption from the rumen of dairy cows as an index of calcium absorption capacity. J. Dairy Sci. 102:5699-5705. https://doi.org/10.3168/jds.2018-16052.

Jørgensen, E., and A. R. Pedersen. 1998. How to obtain those nasty standard errors from transformed data - and why they should not be used. Page 20 in Biometry Research Unit - Internal report 7. Danish Institute of Agricultural Sciences. Accessed Sep. 27, 2020. http://gbi.agrsci.dk/ ejo/publications/dinapig/intrep7.pdf.

Karkalas, J. 1985. An improved enzymic method for the determination of native and modified starch. J. Sci. Food Agric. 36:1019-1027. https://doi.org/10.1002/jsfa.2740361018.

Khorasani, G. R., and D. G. Armstrong. 1992. Calcium, phosphorus, and magnesium absorption and secretion in the bovine digestive tract as influenced by dietary concentration of these elements. Livest. Prod. Sci. 31:271-286. https://doi.org/10.1016/ 0301-6226(92)90022-V.

Khuituan, P., K. Wongdee, W. Jantarajit, P. Suntornsaratoon, N. Krishnamra, and N. Charoenphandhu. 2013. Fibroblast growth factor-23 negates $1,25(\mathrm{OH})_{2} \mathrm{D}_{3}$-induced intestinal calcium transport by reducing the transcellular and paracellular calcium fluxes. Arch. Biochem. Biophys. 536:46-52. https://doi.org/10.1016/j.abb 2013.05.009

Lee, S. M., E. M. Riley, M. B. Meyer, N. A. Benkusky, L. A. Plum, H. F. DeLuca, and J. W. Pike. 2015. 1,25-Dihydroxyvitamin $\mathrm{D}_{3}$ controls a cohort of vitamin $\mathrm{D}$ receptor target genes in the proximal intestine that is enriched for calcium-regulating components. J. Biol. Chem. 290:18199-18215. https://doi.org/10.1074/jbc.M115 .665794 .

Lomba, F., G. Chauvaux, E. Teller, L. Lengele, and V. Bienfet. 1978. Calcium digestibility in cows as influenced by the excess of alkaline ions over stable acid ions in their diets. Br. J. Nutr. 39:425-429. https://doi.org/10.1079/BJN19780058.

Lopez, I., E. Aguilera-Tejero, A. J. Felsenfeld, J. C. Estepa, and M. Rodriguez. 2002. Direct effect of acute metabolic and respiratory acidosis on parathyroid hormone secretion in the dog. J. Bone Miner. Res. 17:1691-1700. https://doi.org/10.1359/jbmr.2002.17 .9.1691.

Martinez, N., C. A. Risco, F. S. Lima, R. S. Bisinotto, L. F. Greco, E. S. Ribeiro, F. Maunsell, K. Galvão, and J. E. P. Santos. 2012. Evaluation of peripartal calcium status, energetic profile, and neutrophil function in dairy cows at low or high risk of developing uterine disease. J. Dairy Sci. 95:7158-7172. https://doi.org/10 $.3168 /$ jds.2012-5812.

Megahed, A. A., M. W. H. Hiew, S. A. El Badawy, and P. D. Constable. 2018. Plasma calcium concentrations are decreased at least 9 hours before parturition in multiparous Holstein-Friesian cattle in a herd fed an acidogenic diet during late gestation. J. Dairy Sci. 101:1365-1378. https://doi.org/10.3168/jds.2017-13376.

Morrissey, J. J., and D. V. Cohn. 1979. Secretion and degradation of parathormone as a function of intracellular maturation of hormone pools. J. Cell Biol. 83:521-528. https://doi.org/10.1083/jcb.83.3 .521 .
NRC. 2001. Nutrient Requirements of Dairy Cattle, 7th rev. ed. Natl. Acad. Press, Washington, DC.

Oberleithner, H., R. Greger, and F. Lang. 1982. The effect of respiratory and metabolic acid-base changes on ionized calcium concentration: in vivo and in vitro experiments in man and rat. Eur. J. Clin. Invest. 12:451-455. https://doi.org/10.1111/j.1365-2362 1982.tb02223.x.

Oehlschlaeger, V., M. Wilkens, B. Schroeder, S. Daenicke, and G. Breves. 2014. Effects of 25-hydroxyvitamin $\mathrm{D}_{3}$ on localization and extent of gastrointestinal calcium absorption in dairy cattle. Anim. Prod. Sci. 54:1394-1398. https://doi.org/10.1071/AN14344.

Ohyama, Y., K. Ozono, M. Uchida, T. Shinki, S. Kato, T. Suda, O. Yamamoto, M. Noshiro, and Y. Kato. 1994. Identification of a vitamin D-responsive element in the $5^{\prime}$ flanking region of the rat 25-hydroxyvitamin $\mathrm{D}_{3}$ 24-hydroxylase gene. J. Biol. Chem. 269:10545-10550.

Piepho, H. P. 2009. Data transformation in statistical analysis of field trials with changing treatment variance. Agronomy. 101:865-869. https://doi.org/10.2134/agronj2008.0226x.

Quinlan, K. P., and M. A. DeSesa. 1955. Spectrophotometric determination of phosphorus as molubdovanadophosphoric acid. Anal. Chem. 27:1626-1629. https://doi.org/10.1021/ac60106a039.

Reinhardt, T. A., J. D. Lippolis, B. J. McCluskey, J. P. Goff, and R. L. Horst. 2011. Prevalence of subclinical hypocalcemia in dairy herds Vet. J. 188:122-124. https://doi.org/10.1016/j.tvjl.2010.03.025.

Rodney, R. M., N. Martinez, E. Block, L. L. Hernandez, P. Celi, C. D. Nelson, J. E. P. Santos, and I. J. Lean. 2018. Effects of prepartum dietary cation-anion difference and source of vitamin D in dairy cows: Vitamin D, mineral and bone metabolism. J. Dairy Sci. 101:2519-2543. https://doi.org/10.3168/jds.2017-13737.

Šafránek, R., M. Holecek, J. Kadlcikova, L. Sprongl, C. Mislanova, M. Kukan, and J. Chladek. 2003. Effect of acute acidosis on protein and amino acid metabolism in rats. Clin. Nutr. 22:437-443. https: //doi.org/10.1016/S0261-5614(03)00041-4.

Samuels, M. H., J. Veldhuis, C. Cawley, R. J. Urban, M. Luther, R. Bauer, and G. Mundy. 1993. Pulsatile secretion of parathyroid hormone in normal young subjects: Assessment by deconvolution analysis. J. Clin. Endocrinol. Metab. 77:399-403.

Santos, J. E. P., I. J. Lean, H. Golder, and E. Block. 2019. Meta-analysis of the effects of prepartum dietary cation-anion difference on performance and health of dairy cows. J. Dairy Sci. 102:2134-2154. https://doi.org/10.3168/jds.2018-14628.

Schonewille, J. T., A. T. Van't Klooster. H. Wouterse, and A. C. Beynen. 1999. Hypocalcemia induced by intravenous administration of disodium ethylenediaminotetraacetate and its effects on calcium in urine of cows fed a high chloride diet. J. Dairy Sci. 82:1317-1324. https://doi.org/10.3168/jds.S0022-0302(99)75355 -5 .

Schröder, B., M. R. Wilkens, G. E. Ricken, S. Leonhard-Marek, D. R. Fraser, and G. Breves. 2015. Calcium transport in bovine rumen epithelium as affected by luminal Ca concentrations and Ca sources. Physiol. Rep. 3:e12615. https://doi.org/10.14814/phy2.12615.

Stewart, P. A. 1983. Modern quantitative acid-base chemistry. Can. J. Physiol. Pharmacol. 61:1444-1461. https://doi.org/10.1139/y83 $-207$.

Takagi, H., and E. Block. 1991. Effects of reducing dietary cationanion balance on calcium kinetics in sheep. J. Dairy Sci. 74:42254237. https://doi.org/10.3168/jds.S0022-0302(91)78618-9.

Valadares, R. F. D., G. A. Broderick, S. C. Valadares Filho, and M. K. Clayton. 1999. Effect of replacing alfalfa silage with high moisture corn on ruminal protein synthesis estimated from excretion of total purine derivatives. J. Dairy Sci. 82:2686-2696. https://doi.org/10 .3168/jds.S0022-0302(99)75525-6.

van Abel, M., J. G. J. Hoenderop, A. W. C. M. van der Kemp, M. M. Friedlaender, J. P. T. M. van Leeuwen, and R. J. M. Bindels. 2005. Coordinated control of renal $\mathrm{Ca}^{2+}$ transport proteins by parathyroid hormone. Kidney Int. 68:1708-1721. https://doi.org/10.1111/ j.1523-1755.2005.00587.x.

Van Cromphaut, S. J., M. Dewerchin, J. G. Hoenderop, I. Stockmans, E. Van Herck, S. Kato, R. J. Bindels, D. Collen, P. Carmeliet, R. Bouillon, and G. Carmeliet. 2001. Duodenal calcium absorption 
in vitamin D receptor-knockout mice: Functional and molecular aspects. Proc. Natl. Acad. Sci. USA 98:13324-13329. https://doi .org/10.1073/pnas.231474698.

Van Soest, P. J., J. B. Robertson, and B. A. Lewis. 1991. Methods for dietary fiber, neutral detergent fiber and nonstarch polysaccharides in relation to animal nutrition. J. Dairy Sci. 74:3583-3597. https://doi.org/10.3168/jds.S0022-0302(91)78551-2.

Vieira-Neto, A., K. N. Galvão, W. W. Thatcher, and J. E. P. Santos. 2017b. Association among gestation length and health, production, and reproduction in Holstein cows and implications for their offspring. J. Dairy Sci. 100:3166-3181. https://doi.org/10.3168/ jds.2016-11867.

Vieira-Neto, A., I. R. P. Lima, F. Lopes Jr., C. Lopera, R. Zimpel, L. D. P. Sinedino, K. C. Jeong, K. Galvão, W. W. Thatcher, C. D. Nelson, and J. E. P. Santos. 2017a. Use of calcitriol to maintain postpartum blood calcium and improve immune function in dairy cows. J. Dairy Sci. 100:5805-5823. https://doi.org/10.3168/ jds.2016-12506.

Vieira-Neto, A., G. Negro, R. Zimpel, M. Poindexter, F. Lopes Jr., W. W. Thatcher, C. D. Nelson, and J. E. P. Santos. 2021. Effects of injectable calcitriol on mineral metabolism and postpartum health and performance in dairy cows. J. Dairy Sci. https://doi.org/10 $.3168 /$ jds. $2020-18448$

Wilkens, M. R., C. Praechter, G. Breves, and B. Schröder. 2016. Stimulating effects of a diet negative in dietary cation-anion difference on calcium absorption from the rumen in sheep. J. Anim. Physiol.
Anim. Nutr. (Berl.) 100:156-166. https://doi.org/10.1111/jpn .12296.

Woudenberg-Vrenken, T. E., R. J. M. Bindels, and J. G. J. Hoenderop. 2009. The role of transient receptor potential channels in kidney disease. Nat. Rev. Nephrol. 5:441-449. https://doi.org/10.1038/ nrneph.2009.100.

Yamagishi, N., M. Miyazaki, and Y. Naito. 2006. The expression of genes for transepithelial calcium-transporting proteins in the bovine duodenum. Vet. J. 171:363-366. https://doi.org/10.1016/j .tvjl.2004.10.021.

Yamashita, H., P. Gao, T. Cantor, T. Futata, T. Murakami, S. Uchino, S. Watanabe, H. Kawamoto, M. Fukagawa, and S. Noguchi. 2003. Large carboxy-terminal parathyroid hormone (PTH) fragment with a relatively longer half-life than 1-84 PTH is secreted directly from the parathyroid gland in humans. Eur. J. Endocrinol. 149:301-306. https://doi.org/10.1530/eje.0.1490301.

Yeh, B., T. Sun, J. Z. Lee, H. Chen, and C. Huang. 2003. Mechanism and molecular determinant for regulation of rabbit transient receptor potential type 5 (TRPV5) channel by extracellular $\mathrm{pH}$. J. Biol. Chem. 278:51044-51052. https://doi.org/10.1074/jbc M306326200.

Zella, L. A., N. K. Shevde, B. W. Hollis, N. E. Cooke, and J. W. Pike. 2008. Vitamin D-binding protein influences total circulating levels of 1,25-dihydroxyvitamin D3 but does not directly modulate the bioactive levels of the hormone in vivo. Endocrinology 149:36563667. https://doi.org/10.1210/en.2008-0042. 